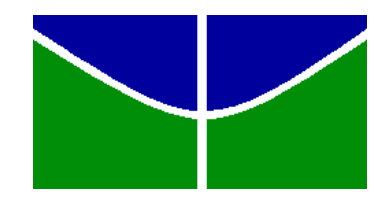

\author{
UNIVERSIDADE DE BRASÍLIA - UNB \\ INSTITUTO DE CIÊNCIAS HUMANAS \\ DEPARTAMENTO DE SERVIÇO SOCIAL \\ TRABALHO DE CONCLUSÃO DE CURSO \\ ORIENTADORA: PROF. ${ }^{\text {a }}$ DR $^{\text {a }}$ DENISE B. B. DE CARVALHO
}

\title{
CRIANÇAS E ADOLESCENTES ABRIGADOS: DIFICULDADES E POSSIBILIDADES DE REINTEGRAÇÃO FAMILIAR
}

\section{ELIENE FERREIRA DA SILVA}




\section{ELIENE FERREIRA DA SILVA}

\section{CRIANÇAS E ADOLESCENTES ABRIGADOS: DIFICULDADES E POSSIBILIDADES DE REINTEGRAÇÃO FAMILIAR}

Trabalho de Conclusão de Curso apresentado ao Departamento de Serviço Social da Universidade de Brasília sob a orientação da Professora Doutora Denise Birche Bomtempo de Carvalho para obtenção do grau de Assistente Social.

\section{Banca Examinadora}

Prof. ${ }^{a}$ Dr. ${ }^{a}$ Denise Birche B. de Carvalho

(Presidente)

Prof ${ }^{a}$. Ms. Ailta Barros de Souza Ramos

Maria Estela Dias Argolo

Brasília, julho de 2009. 


\section{AGRADECIMENTOS}

Agradeço a Deus, eternamente, pelo dom da vida e pelas graças recebidas; pela minha família maravilhosa, pelos amigos e pela realização no meu trabalho e nos meus estudos.

À minha querida e guerreira mãe Maria Salete, exemplo de pessoa, que lutou sozinha e conseguiu, mesmo nas maiores dificuldades, oferecer uma vida com dignidade e respeito a todos os filhos, permitindo que eu chegasse até aqui.

Às minhas amigas Valéria Caetano e Clara Hossell, que sempre ofereceram seus ombros amigos nas horas mais difíceis, incentivando-me sempre a continuar com meus estudos.

Ao meu futuro esposo Wallyson Figueredo, que soube compreender a minha ausência destinada à elaboração deste trabalho, apoiando e fortalecendo-me nas dificuldades encontradas.

A toda minha família, que teve paciência comigo nas horas de estresse, oferecendo-me todo o apoio. Em especial à minha prima Kaliane Vieira e aos meus sobrinhos Ryan e Émilly.

A todas as minhas amigas da graduação que me apoiaram durante esta trajetória acadêmica. Em especial à Regiane, Geucilene, Alessandra, Renata, Raquel e Izabel.

À minha orientadora Denise Bomtempo, que me conduziu na efetivação deste trabalho.

À amiga Estela Argolo, que me apoiou e respondeu sempre com solicitude e paciência às minhas argumentações e inquietações que surgiram durante esta pesquisa.

À Instituição Casa de Ismael, como um todo, que me acolheu e me ofereceu suporte para que eu pudesse realizar este trabalho.

Enfim, a todos que de alguma forma me ajudaram na elaboração deste trabalho. 


\section{Resumo}

Este trabalho objetiva identificar e descrever os motivos que levam as crianças e adolescentes a serem abrigados, bem como os fatores que retardam ou impossibilitam sua reintegração nas famílias de origem, sob à luz do Estatuto da Criança e do Adolescente. $\mathrm{O}$ presente estudo é resultado de uma pesquisa exploratória, com abordagem qualitativa, adotando como técnica o Estudo de Caso realizado na Instituição de abrigamento Casa de Ismael (uma instituição não-governamental situada no endereço SGAN Quadra 913 Norte Conjunto G W/5 - Asa Norte, Brasília - Distrito Federal). Para este estudo foram selecionadas 14 pastas documentais de crianças e adolescentes abrigados, a fim de coletar e analisar os dados. Os resultados encontrados nesta pesquisa referem-se à Violência Doméstica praticada por meio do abandono, da negligência e dos maus tratos - motivos estes que mais ensejaram o abrigamento de crianças e adolescentes. Ainda, fatores econômicos, sociais, afetivos, culturais, simbólicos e psicológicos implicam na ruptura dos laços familiares e dificultam o processo de reintegração familiar. Além disso, as redes de serviços de proteção à família não conseguem dar suporte à sua alta demanda nem conseguem oferecer um acompanhamento eficiente às famílias das crianças e adolescentes em situação de abrigamento. Assim, foi verificado que existem mais dificuldades do que possibilidades para que a reintegração familiar dos sujeitos pesquisados aconteça de fato. O Estado está falhando com a proteção às famílias extremamente pobres, na medida em que não há prioridade para o segmento infanto-juvenil em situação de abrigamento, nem apoio governamental efetivo aos serviços direcionados para atender suas famílias, que estão em estado de vulnerabilidade social. Por outro lado, algumas famílias precisam reconhecer suas dificuldades e problemas para que se faça um trabalho efetivo e, assim, seja possível a reintegração familiar de crianças e adolescentes em situação de abrigamento o mais breve possível.

Palavras-chave: pobreza; violência doméstica; medida de abrigamento; reintegração familiar. 


\section{Resumen}

Este trabajo tiene por objetivo identificar y describir los motivos que llevan niños y muchachos al abrigo y también los factores que retardan o inviabilizan la reitegración a sus familias de origen, con base en el Estatuto da Criança e do Adolescente. El presente estudo es resultado de una investigación exploratoria, con abordagen cualitativa, adoptando como tecnica el Estudo de caso, realizado en una instituición de abrigamiento, llamada Casa de Ismael. Esta instituición no pertenence al gobierno, su dirección es SGAN Quadra 913 Norte - Conjunto G W/5 - Asa Norte, Brasília - Distrito Federal. Para este estudo fue seleccionada 14 pastas documentales de niños y muchachos que están en el abrigo con la finalidad de colectar y analisar los datos. Los resultados encontrados en la investigación se refieren a la Violencia Domestica, por medio del abandono, negligencia y malos tratos como motivos que más ocasionarán abrigamientos de niños y muchachos. Aún, factores economicos, sociales, afectivos, culturales, simbólicos y psicológicos implican en la ruptura de los lazos familiares y dificultan el proceso de reintegración familiar. Además, las redes de servicios de protección a la familia no consiguen dar suporte a alta demanda ni conseguen ofrecer un acompañamiento eficiente a las familias de los niños y muchachos en situación de abrigamiento. Así, fue verificado que existen más dificultades de lo que posibilidades para que la reintegración familiar de las personas investigadas ocurra de hecho, tendo en vista que el Estado falla en la protección de familias extremamente pobres, en la medida que no hay prioridad para el segmento de la niñez en situación de abrigamiento, ni apoyo gobernamental efectivo a los servicios direccionados para atender las familias que están en estado de vulnerabilidad social. Por otro lado, algunas familias necesitan reconocer sus dificultades y problemas para que se haga un trabajo efectivo y, de este modo, sea posible la reintegración familiar de niños y muchachos en situación de abrigamiento el más breve posible.

Palabras llaves: pobreza, violencia domestica, abrigamiento y restruturación familiar. 


\section{LISTA DE ABREVIATURAS E TABELAS}

\section{Lista de Abreviaturas}

A. S. - Acompanhamento Social

CASEL - Casa de Ismael

CF - Constituição Federal

ECA - Estatuto da Criança e do Adolescente

Rel. Inf. - Relatório Informativo

VIJ - Vara da Infância e da Juventude

LOAS - Lei Orgânica da Assistência Social

ONG - Organização Não governamental

BPC - Benefício de Prestação Continuada

IBGE - Instituto Brasileiro de Geografia e Estatística (IBGE)

PNAD - Pesquisa Nacional de Amostra de Domicílios (PNAD)

ASFAM - Associação Sócio-Familiar

art. - artigo

alín. - alínea

\section{Lista de Tabelas}

Tabela 1 - Perfil das famílias dos Sujeitos abrigados

Tabela 2 - Perfil da Violência Doméstica

Tabela 3 - Perfil dos Serviços de Proteção Social às Famílias dos Sujeitos pesquisados

Tabela 4 - Perfil do tempo de abrigamento das crianças e adolescentes 


\section{Sumário}

Resumo. .04

Resumen .05

Lista de Abreviaturas e Tabelas .06

CAPÍTULO I - CONSTRUINDO O OBJETO $\mathrm{E}$ A

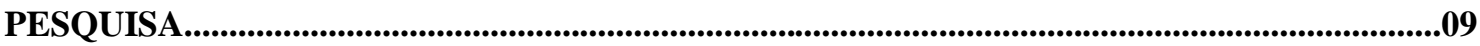

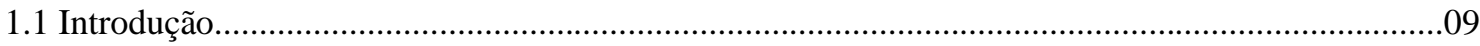

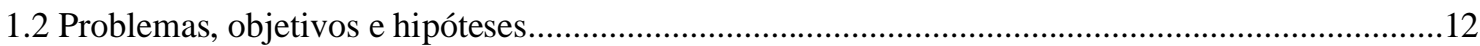

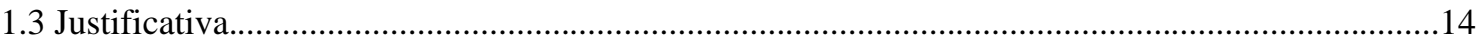

1.4 Metodologia

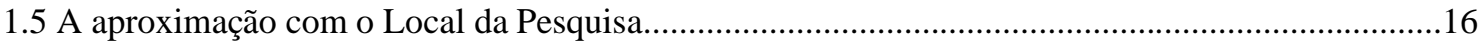

CAPÍTULO II - FAMÍLIA, ROMPIMENTOS DOS LAÇOS FAMILIARES NO CONTEXTO

DO ABRIGAMENTO INFANTO-JUVENIL_.............................................................................................18

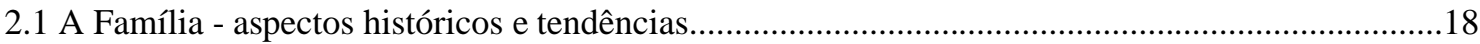

2.1.1 O lugar ideal para a segurança e o desenvolvimento da criança e do adolescente.........................21

2.1.2 O perfil das famílias que tiveram seus filhos abrigados..............................................................22

2.1.3 Fatores que influenciaram na ruptura do vínculo familiar..........................................................24

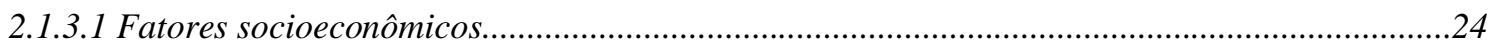


2.1.3.4 Fatores simbólicos e psicológicos.

CAPÍTULO III - A VIOLÊNCIA DOMÉSTICA CONTRA CRIANÇAS E ADOLESCENTES

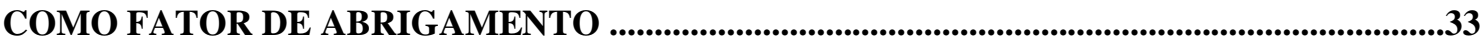

3.1 A Violência Doméstica e Intra-familiar contra crianças e adolescentes .33

3.1.1 Tipos de Violência contra crianças e adolescentes. .34

3.1.2 Negligência e Abandono .35

3.1.3 Maus Tratos 31

3.1.4 Violência Sexual .38

3.2 O perfil da violência doméstica sofrida pelas crianças e adolescentes .39

3.3 A Suspensão do Poder Familiar e o Processo de Abrigamento Infanto-Juvenil 42

CAPÍTULO IV - A PROTEÇÃO DO ESTADO: DO ABRIGAMENTO À REINTEGRAÇÃO FAMILIAR .45

4.1 A Política de Assistência Social - breve histórico. .45

4.1.1 O Estado e a proteção às Famílias . .48

4.2 A co-responsabilidade na garantia dos direitos do segmento infanto-juvenil

4.2.1 A atuação da Casa de Ismael na garantia dos direitos sociais do seu público-alvo. .50

4.3 Os Serviços de Proteção Social às Famílias dos Sujeitos abrigados. .53 
4.5 O trabalho da CASEL com as famílias dos sujeitos abrigados visando à reintegração

familiar . .56

CONSIDERAÇÕES FINAIS. . .58

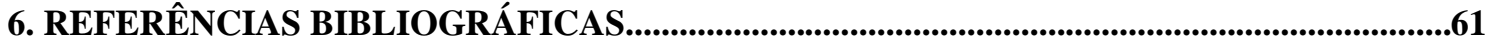

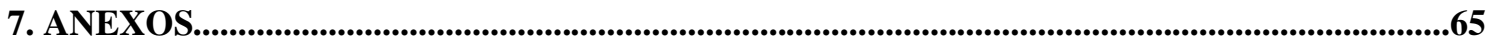

7.1 Anexo I - Síntese das Famílias dos Sujeitos abrigados................................................................65

7.2 Anexo II - Autorização da Casa de Ismael para realizar a Pesquisa..................................................68

7.3 Anexo III - Modelo de Relatório Informativo consultado .69 


\section{Capítulo I}

\section{Construindo o Objeto e a Realidade da Pesquisa}

\subsection{Introdução}

Muitos estudos têm abordado a temática CRIANÇAS E ADOLESCENTES, revelando a realidade de outrora e a atual o que esse segmento tem vivenciado durante o processo histórico da sociedade brasileira. Entretanto, discutir acerca dos motivos que levaram ao abrigamento de crianças e adolescentes e a possibilidade de sua reintegração familiar não é fácil, pois parte-se do pressuposto de que a responsabilidade não é só da família, a qual é permeada por processos complexos que envolvem várias dimensões, mas também da sociedade e do Estado que têm a abandonado.

No Brasil, o auge das institucionalizações de crianças se dá a partir do século XVIII, nas Santas Casas e nos hospitais, por meio de um dispositivo chamado "Roda dos expostos", com o intuito de evitar o aborto, o infanticídio e o abandono de crianças que eram alarmantes nesse período. $\mathrm{O}$ ato de abandonar, mesmo praticado por famílias sem condições de garantir o cuidado e o sustento dos filhos, era considerado como desamor e irresponsabilidade dos pais. Contudo, constituía-se a única forma de essas famílias conseguirem o apoio público na criação de seus filhos (VENÂNCIO, 1999).

Entretanto, essas instituições não possuíam condições ideais e salubres que garantissem sobrevivência a todas as crianças. Assim, muitas crianças não alcançaram sequer o primeiro ano do abandono (idem). Desse modo, mesmo "amparada" a infância ainda permanecia num estado de abandono social. Essa institucionalização não conseguia oferecer condições saudáveis para essas crianças, fazendo com que médicos higienistas, juntamente com juristas, conseguissem a extinção dessas Rodas (MARCÍLIA, 1998).

Neste ínterim, a filantropia ganha espaço para atuar, de forma racional e técnica, a questão do abandono infantil. A ideologia da filantropia pautava-se na solução do problema pela via da educação. A criança seria disciplinada e normatizada, preparando-a para o trabalho e para a formação da família. O objetivo era assegurar a ordem e afastar o perigo que este segmento abandonado representava para a sociedade (idem). Neste sentido, a criança desvalida não era centro de atenção para a intervenção do Estado, tanto no âmbito da 
assistência quanto no âmbito da proteção. O Estado apenas se preocupava com a ordem e o controle do menor abandonado.

A criança passa a ganhar um pouco de atenção apenas em 1967, com o Estatuto do Menor. Todavia, esse Código não abordava direitos para as crianças, mas visava apenas prevenir ou corrigir o seu "desajustamento". Sob essa ideologia, a família é tida como propulsora dessa nova ação. O lócus familiar é visto como local ideal para que a criança seja socializada e capacitada para o desempenho das funções sociais (MARCÍLIO, 1998).

Apenas com a Constituição Federal de 1988 e a aprovação do Estatuto da Criança e do Adolescente (lei 8069/90) é que realmente todas as crianças e adolescentes são vistos sob a perspectiva de direitos, como cidadãos. Agora, não só a família, mas a sociedade e o Estado têm o dever de garantir e assegurar os seus direitos.

Entretanto, apesar de ter sido reconhecido como cidadão de direitos, esse segmento infanto-juvenil é o mais exposto às conseqüências da exclusão social (FÁVERO, 2001). São indivíduos que têm famílias, mas que estão separados delas por vários fatores, como: a pobreza, a miséria, a violência doméstica. Estes, por sua vez, implicam na ruptura de laços familiares e levam ao abrigamento de milhares de crianças e adolescentes.

A convivência familiar e comunitária é um direito reconhecido para aqueles que estão em fase de desenvolvimento e formação da personalidade, mas está sendo desrespeitada, alijando de milhares de crianças e adolescentes o que lhes é assegurado em lei (art.19, ECA).

Neste sentido, Silva (2004) identificou cerca de 20 mil crianças e adolescentes institucionalizados nos abrigos pesquisados no país ${ }^{1}$, o que mostra que apesar de a legislação ter avançado em relação aos direitos desse segmento, não é suficiente para que seus direitos sejam cumpridos de fato.

O abrigamento de crianças e adolescentes que, de acordo com o ECA, deveria ser provisório, visando à "reestruturação" das famílias, ou seja, até que se consiga as condições favoráveis para que seus filhos retornem para o convívio familiar, na realidade é bastante diferente do que a lei estabelece. Essa institucionalização está se tornando uma medida "permanente" para a maioria das crianças e adolescentes abrigados que estão passando toda sua infância e/ou adolescência nessas instituições. O "Levantamento Nacional de Abrigos para Crianças e Adolescentes" (SILVA, 2004) revelou que o tempo de duração da institucionalização pode perdurar entre uma variação de dez anos ou mais. Isto significa que

\footnotetext{
1 A pesquisa "O direito à convivência familiar e comunitária: os abrigos para crianças e adolescentes no Brasil" foi realizada nacionalmente apenas nos abrigos que estavam cadastrados na Rede de Serviços de Ação Continuada - Rede SAC.
} 
uma criança que é abrigada aos oito anos de idade provavelmente sairá da instituição apenas quando alcançar sua maioridade.

As famílias necessitadas deveriam receber o apoio governamental para superação da pobreza e exclusão social, fatores que mais prejudicam o segmento infanto-juvenil. Situação essa que se configura como um paradoxo diante do art. 23 do ECA, o qual preconiza que a falta de recursos materiais não constitui em si motivo suficiente para a perda ou suspensão do poder parental, obrigando a inclusão dessas famílias em programas oficiais de auxílios. Contudo, as famílias que não têm meios de oferecer as condições mínimas que garantam a sobrevivência dos filhos são obrigadas a se separar deles, visto que nos abrigos receberão alimentos e serão inclusos em outras políticas sociais. Porém, ressalta-se que esses ambientes não são os mais propícios para que esses filhos possam se desenvolver de forma saudável.

Além de fatores como a pobreza e a indigência - que mais levam à ruptura do convívio familiar de crianças e adolescentes -, a cultura brasileira também se determina como um obstáculo na Adoção desses sujeitos, pois a sociedade se pauta no status de perfis e modelos de felicidade, sem se preocupar com as reais satisfações individuais e coletivas.

Cabe ressaltar que a maioria dessas crianças e adolescentes vai para instituições de abrigamento não-governamentais, cujos recursos são escassos. Por este motivo, grande parte dos profissionais dessas entidades é voluntária, como psicólogos, médicos, dentistas, entre outros. Isso implica em prejuízo para o atendimento da demanda que necessita desses cuidados especializados, pois esses profissionais não disponibilizam de tempo determinado para atender aos abrigados, quando necessário. Ademais, as mães sociais responsáveis pelo cuidado direto dessas crianças e adolescentes são pessoas de baixo nível escolar, pobres, sem preparo e conhecimento para lidar com o surgimento das situações complexas dos usuários. Isso significa que esse lugar não é o ideal para que crianças e adolescentes permaneçam por muito tempo.

Analisando o aspecto das mães sociais, David, Falk e Golse (2001, 2002 apud NOGUEIRA \& COSTA, 2005) entendem que essa função pode ser decisiva e que esses cuidados sem qualificação correm o risco de desumanizar a criança, prejudicando sua adaptação e contribuindo de forma negativa à sua possibilidade de desenvolvimento e estruturação psíquica.

Sob a mesma perspectiva, Carvalho (2003) menciona que o ambiente institucional não se configura num ambiente adequado para o desenvolvimento da criança e do adolescente, visto que elementos como a proporção de criança por cuidador, o atendimento padronizado, a escassez de atividades planejadas e a fragilidade das redes de apoio social e afetivo podem 
acarretar prejuízos aos indivíduos que vivem nessas instituições (2002, apud SIQUEIRA \& DELL'AGLIO, 2006).

Por outro lado, autores afirmam que, em algumas situações, o abrigo pode ser um ambiente mais saudável do que alguns lares afetados física e socialmente, impedindo o desenvolvimento da criança (CLARKE \& CLARKE, 1976, apud SIQUEIRA \& DELL'AGLIO, 2006).

Para assegurar o pleno desenvolvimento das crianças e adolescentes, o ECA estabelece a responsabilidade da família, da sociedade e do Estado em assegurar que a criança e o adolescente tenham absoluta prioridade acerca do direito à vida, saúde, alimentação, educação, lazer, profissionalização, cultura, dignidade, respeito, liberdade e à convivência familiar e comunitária. No entanto, muito pouco tem acontecido para que esses direitos sejam garantidos e efetivados. O que se verifica é a violação dos direitos humanos desse segmento infanto-juvenil, que tem sofrido todas as formas de negligência, discriminação, exploração, violência, crueldade e opressão ao longo do processo histórico da sociedade.

Ademais, a instituição familiar que deveria proporcionar os cuidados necessários para o pleno desenvolvimento dos seus filhos não consegue dar conta de sua função primordial, pois sem o acesso à riqueza socialmente produzida, somado ao desemprego e à falta de moradia, entre outros problemas sociais, tudo isso tem contribuído para que famílias alijadas das condições básicas de sobrevivência se lancem ao alcoolismo como forma de refúgio, mas que apenas aumenta o conflito familiar e faz emergir diversas formas de violência no lócus familiar.

Ainda, a falta de políticas públicas efetivas que possam dar condições a essa importante instituição familiar dificulta que se assegure a garantia do direito à convivência familiar e comunitária dessas crianças e adolescentes que estão perdendo não só o seu direito, mas a sua referência familiar como cidadão, pois sua permanência em abrigos é bastante prolongada.

\subsection{Problema, objetivos e hipóteses}

Diante desse quadro paradoxal apresentado acerca da realidade de crianças e adolescentes em situação de abrigamento, o presente estudo visa realizar uma pesquisa exploratória com o objetivo de verificar as dificuldades e possibilidades da reintegração familiar numa instituição não governamental de abrigamento, no Distrito Federal. Em face desta problemática foi formulada a seguinte pergunta: Por que crianças e adolescentes, em 
situação de abrigamento, permanecem institucionalizados por muito tempo, ao invés de serem reintegrados em suas famílias de origem, de acordo com o que preconiza o Estatuto da Criança e do Adolescente.

Os objetivos que perpassam a construção do objeto da pesquisa são:

\section{Objetivo geral}

- Identificar e descrever os motivos que levam as crianças e adolescentes a serem abrigadas pela Rede de Proteção, bem como os fatores que retardam ou impossibilitam a sua reintegração familiar.

\section{Objetivos específicos}

- Identificar as razões que ensejaram o abrigamento de crianças e/ou adolescentes, no lócus da família biológica;

- Identificar quais são as violências sofridas pelas crianças e adolescentes que influenciam no abrigamento;

- Verificar se essas famílias estão inseridas em programas de apoio à família, como a rede de atenção de proteção social básica e/ ou proteção social especial, quando necessário, visando à proteção social das famílias e dos seus indivíduos.

- Verificar quais os procedimentos adotados pela instituição de abrigo, sob a perspectiva de reestruturar a família, a fim de possibilitar a reintegração desse segmento infanto-juvenil imerso nessa situação de abrigamento.

Para responder à questão de fundo, que perpassa a construção do objeto e a realidade da pesquisa, foram elaboradas três hipóteses: 1) Os fatores sociais, econômicos, afetivos, culturais, simbólicos e psicológicos implicam na ruptura familiar e dificultam o processo de reintegração familiar; 2) A violência doméstica, por meio da negligência, do abandono, dos maus tratos e do abuso sexual - fatores que mais influenciam no abrigamento do segmento infanto-juvenil; 3) As redes de serviços, bem como os programas direcionados ao auxílio e à proteção familiar, não conseguem proporcionar às famílias de crianças e adolescentes abrigados condições suficientes para que possam superar sua situação de vulnerabilidade social, cuja decorrência advém da pobreza e privações, como condições de habitação, segurança alimentar, trabalho, geração de renda e etc., implicando, dessa forma, na morosidade ou até mesmo na impossibilidade da reintegração familiar dentro da perspectiva do Estatuto da Criança e do Adolescente. 


\subsection{Justificativa}

O interesse pelo tema surgiu a partir de algumas leituras acerca da temática e, principalmente, da experiência de Estágio realizada numa Instituição de Abrigamento para Crianças e Adolescentes, onde fui sensibilizada face àquela realidade concreta da população infanto-juvenil. Além disso, como estudante e futura profissional de Serviço Social, cuja função essencial é a garantia de direitos, é sob esta perspectiva que se justifica a relevância em estudar a problemática, com o objetivo de identificar os entraves que dificultam a reintegração familiar dessas crianças e adolescentes abrigados.

Nota-se que crianças e adolescentes circunscritos nessa situação de abrigamento estão com os seus direitos duplamente violados, uma vez que o motivo de abrigamento é a ameaça ou violação de seus direitos, e a sua permanência nesses abrigos se configura em mais uma violação: a não garantia do direito à convivência familiar e comunitária (SILVA, 2004).

Assim, esta pesquisa visa contribuir, no sentido de identificar elementos para incentivar mais discussões acerca da temática, identificando as causas do problema a fim de despertar a atenção dos poderes públicos para que ações sejam priorizadas e destinadas para esses sujeitos. Desse modo, a realidade concreta dessa população poderá ser transformada, possibilitando a essas crianças e adolescentes a garantia e a efetivação - pelo Estado, família e sociedade - dos seus direitos, assegurando-lhes melhores condições de vida e seu desenvolvimento saudável.

\subsection{Metodologia}

A pesquisa buscou identificar e descrever as razões que levam crianças e adolescentes a serem abrigados pela Rede de Proteção Social, bem como os fatores que retardam ou impossibilitam a sua reintegração familiar.

Dessa forma, partindo das hipóteses já citadas, procurou-se responder à seguinte questão de fundo: Por que crianças e adolescentes, em situação de abrigamento, permanecem institucionalizados por muito tempo, ao invés de serem reintegrados em suas famílias de origem, de acordo com o que preconiza o Estatuto da Criança $e$ do Adolescente?

Diante dessa problemática, adotou-se a pesquisa Exploratória com a abordagem qualitativa, cujo objetivo é proporcionar uma visão geral com a aproximação pesquisadorfenômeno, visando ao aprimoramento das idéias e o desvelamento de intuições (GIL, 2008). 
Neste sentido, a pesquisa assumiu a forma de um Estudo de Caso numa instituição de abrigamento, no Distrito Federal - A Casa de Ismael, cujas características serão apresentadas no item 1.5. Goldenberg (2003) aconselha a utilização do Estudo de Caso, pois não o considera meramente uma técnica, mas uma análise holística, a qual pode reunir o maior número de informações detalhadas, tornando o estudo o mais completo possível, apreendendo toda a complexidade da estrutura social estudada, seja um indivíduo, uma família, uma instituição ou uma comunidade, com o objetivo de compreendê-los em sua realidade social. Na concepção de Creswell (2007), o Estudo de Caso permite que o pesquisador explore, em profundidade, fatos, processos, um ou vários indivíduos, coletando informações detalhadas e dados durante um período de tempo prolongado, por meio de uma variedade de procedimentos.

Para coleta, análise e interpretação dos dados foram seguidos três caminhos:

(i) O primeiro fez-se um levantamento de bibliografia, referencial teórico referente à problemática em questão.

(ii) No segundo escolheram-se os documentos para serem submetidos à análise. Fez-se uma amostragem, reduzindo o universo para que fosse possível alcançar a análise (BARDIN, 1995). A partir disso, no universo de 50 pastas, 14 pastas foram selecionadas para realização da pesquisa, por se tratar de sujeitos que estavam em processo de reintegração familiar, podendo fazer uma análise mais específica (idem, 1995).

(iii) No terceiro foi a exploração do material, categorização e interpretação dos dados. Para a exploração do material foram escolhidos dois instrumentos: o Relatório Informativo e o Acompanhamento social documentos integrantes das pastas dos sujeitos abrigados. Os dados foram categorizados, permitindo maior aproximação do pesquisador às situações vivenciadas e o contexto social em que estavam inseridas as crianças e adolescentes, bem como as suas famílias de origem. Assim foi possível, no cerne dessa problemática, "conhecer as diversas situações e relações que ocorreram na vida social, [...] econômica e demais aspectos do comportamento" desse segmento populacional e de sua família na sua realidade concreta (CERVO \& BERVIAN, 1996)

O Relatório Informativo mencionado acima informa a situação biopsicossocial das crianças e adolescentes abrigados, bem como a realidade concreta de suas famílias ao Juiz da 
VIJ, a fim de subsidiá-lo em suas decisões acerca da situação desse segmento infanto-juvenil. Já o Acompanhamento Social comporta elementos reveladores dos aspectos cotidianos vivenciados pelo segmento populacional na instituição.

Optou-se por essa técnica indireta - coleta de dados por meio de documentos - por oferecer condições de obter dados suficientes, evitando perda de tempo e constrangimento à população infanto-juvenil, quando obtidos diretamente (Gil, 2008), a fim de não auferir sofrimento a esses sujeitos, diante da situação em que se encontravam.

\subsection{A aproximação com o Local da Pesquisa ${ }^{2}$}

O meu primeiro contato com a Casa de Ismael foi em março de 2008, período que iniciei a segunda fase do Estágio Curricular nesta Instituição, finalizando-o no início de julho de 2008. Diante daquela primeira abordagem exploratória, conheci a realidade do segmento infanto-juvenil em situação de abrigamento e fui despertada a conhecer mais profundamente a problemática em questão. Assim, a segunda aproximação estabeleceu-se a partir da segunda metade do ano de 2008, quando iniciada a pesquisa; e finalizou-se com a coleta de dados em fevereiro de 2009. Após a coleta do material, distanciei-me do campo da pesquisa para que os dados fossem catalogados e analisados de forma objetiva.

A Casa de Ismael - Lar da Criança - representa uma grande participação da Sociedade Civil em assegurar e proteger as crianças e adolescentes, enquanto afastados do convívio familiar. A sua origem consta desde a fundação do Departamento do Centro Espírita - O Consolador - por um grupo de pessoas espíritas, em 23.10.1964. Posteriormente, foi reconhecida como utilidade pública federal pelos Decretos $n^{\circ} 72.171 / 73$ e $n^{\circ} 20.074 / 68$. A referida Instituição também é reconhecida como CASEL. Atualmente situa-se no endereço SGAN Quadra 913 Norte - Conjunto G W/5 - Asa Norte, Brasília - Distrito Federal.

A Casel é uma instituição Assistencial sem fins lucrativos, que oferece assistência às crianças e adolescentes em situação de risco e vulnerabilidade social. Atende à população do Distrito Federal e Entorno. Para atender toda demanda, a Casa de Ismael conta com a participação de profissionais voluntários, funcionários, estudantes universitários e outros. A sua atuação é em regime de Abrigo - abrigamento para crianças e adolescentes; Sócioeducativo em Meio Aberto - o atendimento é feito pelo sistema de Creche, onde as crianças

\footnotetext{
2 Informações retiradas do Relatório de atividades, Balanço e Demonstração de Resultado, 2006 e do Relatório Informativo - Orçamento, planos de Ação e Aplicação e Planejamento Estratégico, 2008 da CASEL.
} 
são cuidadas e educadas; e Apoio e Orientação Sócio-familiar - são visitas domiciliares aos pais biológicos identificados.

A demanda que chega nessa Instituição é constituída por crianças, a partir dos dois anos de idade, e adolescentes. A CASEL atende aproximadamente 51 crianças e adolescentes sob medida de abrigamento, que são encaminhados para uma casa-lar ${ }^{3}$, com no máximo cinco crianças abrigadas, que ficam sob a responsabilidade de pais sociais ou mãe social.

O programa de abrigamento é executado em parceria com o poder público local e a sociedade civil. O poder público oferece uma renda per capita e a sociedade civil oferece doações e serviços ${ }^{4}$. Entretanto, percebe-se que esses recursos não são suficientes para suprir todas as necessidades das crianças e dos adolescentes, pois o Estado oferece uma quantia muito pequena somada às doações que sofre constante variação.

Ao propor esta pesquisa, partiu-se do pressuposto de que as informações contidas nas pastas dos sujeitos abrigados dariam conta da aproximação e conhecimento das dificuldades e possibilidades da reintegração familiar de crianças e adolescentes abrigados. Entretanto, no final da elaboração deste trabalho, perceberam-se algumas lacunas nos documentos pesquisados, sendo necessário outro contato com a Instituição para complementação dos dados. Assim, foi possível efetivar o estudo e alcançar os resultados.

Este trabalho está dividido em quatro capítulos. O primeiro capítulo faz uma abordagem acerca da problemática da pesquisa, descreve o objeto e a metodologia utilizada, e apresenta a Instituição pesquisada. O segundo traz algumas aproximações teóricas sobre o conceito de Família, a discussão dos fatores que influenciam no rompimento dos laços familiares, bem como a sua implicação na reintegração familiar. O terceiro capítulo tem como quadro teórico a Violência Doméstica contra Crianças e Adolescentes, ressaltando os tipos desse fenômeno mais sofridos pelos sujeitos pesquisados. O quarto capítulo traz um breve histórico sobre a Assistência Social no Brasil, tendo como pressuposto a proteção social às famílias e a co-responsabilidade do Estado e da Sociedade Civil em assegurar os direitos do segmento infanto-juvenil. Finalizando tem-se as Considerações Finais, em que são respondidas as hipóteses da pesquisa e a pergunta que a norteou.

\footnotetext{
3 De acordo com a Lei no. 7.644, de 18 de dezembro de 1987, casas-lares são unidades residenciais sob responsabilidade de mãe social, que abrigue até dez crianças e/ou adolescentes.

Informações retiradas do Relatório de atividades, Balanço e Demonstração de Resultado, 2006 e do Relatório Informativo - Orçamento, planos de Ação e Aplicação e Planejamento Estratégico, 2008 da CASEL.
} 


\section{Capítulo II}

\section{Família e Rompimentos dos Laços Familiares no Contexto do Abrigamento Infanto-Juvenil}

\subsection{A Família - aspectos históricos e tendências}

Recorrendo a algumas literaturas percebe-se que há um consenso entre a maioria de autores acerca da não existência de um conceito que abarque toda a complexidade da família. Essa instituição, ao longo do processo evolutivo da sociedade, tem sofrido grandes transformações em sua estrutura interna, apresentando-se com particularidades específicas relativas a cada grupo social.

De acordo com Bach (1983) existiam três modelos históricos de família: (i) o Patriarcal, constituído por um conjunto de famílias que se submetem à autoridade do patriarca, onde a propriedade é comum a todos os integrantes e a sociedade é fundada na atividade agropastoril especializada; (ii) a família Doméstica, restrita na unidade familiar com relativa independência, possui autonomia econômica e cultural, sendo auto-suficiente; (iii) a família Nuclear, mais apta a morar na cidade e seus integrantes têm maior consciência pessoal.

Com a evolução das sociedades, a família começa a enfrentar vários processos de modificação em seus relacionamentos interno e externo. Bach (1983) relata que a realidade socioeconômica e cultural da família já não tinha mais simetria com o que foi imposto pelo tratamento teórico-jurídico de outrora. O modelo oficial, cujas regras eram impostas pelas macroinstituições (Estado e Igreja) às famílias, não conseguia responder aos anseios dos membros das famílias.

Neste sentido, Barsted (1987), sob uma perspectiva histórica, relata que o Código Civil brasileiro de 1926 considerava apenas como legítima a família oriunda do matrimônio. Entretanto, com o progresso da sociedade, surgem novos arranjos familiares que estão diretamente ligados às mudanças no modo de produção capitalista. Pode-se notar modificações na estrutura interna, alteração nos padrões sociais e culturais, bem como mudanças em tamanho, modelo e papel da família. 
A partir dessas transformações na estrutura familiar e por meio das requisições da sociedade, a Constituição Brasileira de 1988 passou a abarcar uma nova configuração para a família. Esta Carta Magma passou a reconhecer a família como uma comunidade formada pelos pais ou por apenas um dos pais e seus descendentes, entendida como ente fundamental para a sociedade (ROSA, 2006).

O ECA vai além e reconhece dois tipos de família a natural ou biológica e a família substituta. A primeira é definida em seu art. 25 como uma instituição em que pelo menos um dos pais biológicos esteja presente com os seus descendentes. Na segunda, a relação entre os membros transcende a questão dos laços consangüíneos. Neste trabalho será adotado o conceito preconizado pelo ECA acerca da família natural ou biológica para análise do presente estudo.

A partir dessas novas abordagens sobre a família, nota-se que ela passa a ser vista não mais como aquela formada pelo tripé pai-mãe-filho, mas como uma unidade flexível que pode ser composta por um(a) só genitor(a) ou os dois genitores ao mesmo tempo e seus descendentes, desvinculando-se do modelo de família nuclear e transcendendo a outro modelo que até então não era reconhecido legalmente - a família substituta. Este último modelo familiar é formado por meio de um processo legal, em que o adotado passa a participar de todos os direitos e deveres que possui o filho ligado pelos laços consangüíneos (CAVALCANTE \& JORGE, 2008).

Nesse novo contexto, a família brasileira contemporânea passa a apresentar diversas formas singulares. O Instituto Brasileiro de Geografia e Estatística (IBGE), por meio da Pesquisa Nacional de Amostra de Domicílios (PNAD), revela que a maioria das famílias (50\%) ainda é constituída por pais e filhos morando no mesmo domicílio, mas há uma tendência à redução no tamanho da família devido à diminuição da fecundidade e ao crescimento de famílias chefiadas por mulheres (18,2\%) (IBGE, 2005).

Por outro lado, surgem outras configurações familiares, como famílias formadas por casais homossexuais com filho adotivo, famílias monoparentais que são chefiadas, na maioria das vezes, por mulheres. Sem dúvida, esses novos aspectos familiares ressaltados pelo IBGE são conseqüências das transformações culturais ocorridas nas últimas décadas no mundo industrializado, resultando em novos arranjos familiares.

É importante ressaltar que, apesar dessas metamorfoses na estrutura familiar, esta não perdeu a sua importância como ente protetor e socializador. Neste sentido, Kaloustian e Ferrari (1998, p.11-12 apud GOMES \& PEREIRA, 2005) afirmam que família "é o espaço indispensável para a garantia da sobrevivência de desenvolvimento e da proteção integral dos 
filhos e demais membros, independente do arranjo familiar ou da forma como vem se estruturando". Bach (1983), em sentido mais amplo, considera a família como entidade original e sui generis cujo papel é "servir de elo de transmissão, de passagem e transição entre os indivíduos e a sociedade". A família funciona como uma das mais importantes agências educadoras, possibilitando ao indivíduo desenvolver-se de forma livre, consciente e criativa e conviver socialmente, integrando-se em comunidade e criando valores morais aceitáveis.

Preocupado com a compreensão que se faz acerca da família, o Plano Distrital de Promoção, Proteção e Defesa do Direito de Crianças e Adolescentes à Convivência Familiar e Comunitária (SEDEST, 2008, p. 100) ressalta que a instituição familiar deve ser

compreendida como um grupo de pessoas com laços de consangüinidade, de aliança, de afinidade, de afetividade ou de solidariedade, cujos vínculos circunscrevem obrigações recíprocas, organizadas em torno de relações de geração e de gênero. Arranjos familiares diversos devem ser respeitados e reconhecidos como potencialmente capazes de realizar as funções de proteção e de socialização de suas crianças e adolescentes.

Compreende-se a partir desses conceitos que não importa qual seja a configuração das famílias. Independentemente do modelo familiar deve-se reconhecer, respeitar e acreditar que elas são capazes de cumprir com a sua função de proteção, cuidados, alimentação, afeto e socialização dos indivíduos.

Diante do exposto, conclui-se que não há modelo, forma ou arranjo familiar que determine um padrão ideal estabelecido para compreender a família na contemporaneidade, visto que ela é extremamente complexa e permeada por metamorfoses durante todo o processo histórico da sociedade. Mas, independentemente de suas formas e arranjos, ela é uma instituição social importantíssima no progresso da humanidade, bem como nas relações interpessoais e sociais (instituição fundamental no alicerce da construção do indivíduo).

Portanto, quando se desenvolve um estudo que contemple a família, é necessário conhecer as novas formas e arranjos apresentados por essa entidade social para conhecer as suas reais condições socioeconômica, psicossocial e suas potenciais capacidades - conjunto de fatores que se modificam com a transição da história - com o objetivo de fazer uma análise e, assim, vislumbrar estratégias que possam, de fato, retirá-las das situações de risco e vulnerabilidade social, principalmente aquelas famílias exclusas do processo de riqueza socialmente produzida. 


\subsubsection{O lugar ideal para a segurança e o desenvolvimento saudável das crianças e adolescentes}

A família ocupa um lugar central no desenvolvimento das crianças e dos adolescentes. $\mathrm{Na}$ fase da vida infantil são transmitidos os valores, as normas de comportamento, de conduta, hábitos familiares, crenças, costumes, bem como o respeito intergeracional. A família, assim, torna-se um pilar fundamental na construção do cidadão, preparando-o para, posteriormente, se relacionar de forma mais ampla com a sociedade.

Existem dois tipos de socialização que o indivíduo recebe durante a sua formação. A primeira refere-se à socialização primária, transmitida às crianças pelas figuras de autoridade no seu âmbito familiar, preparando-as para lidar com o mundo real. A segunda diz respeito à socialização secundária, originada da relação entre outros agentes e instituições com as quais as crianças irão conviver, trazendo novos valores e significados que serão acrescidos ou contrapostos àqueles adquiridos. (AMAS, 1995)

O espaço familiar, além de ser indispensável para a socialização dos indivíduos, garante a sobrevivência, o desenvolvimento saudável e a proteção integral da parcela da população mais fragilizada, como crianças, adolescentes e idosos. Independentemente do modelo de família adotado, o objetivo maior é alcançar garantias e condições seguras para eles. Assim, a família visa garantir à população infanto-juvenil os direitos fundamentais como a vida, saúde, educação, alimentação e lazer. Além de proporcionar um ambiente saudável que ofereça condições para seu pleno desenvolvimento.

Outros fatores importantes para o desenvolvimento da personalidade das crianças e adolescentes são o afeto, o carinho e o amor transmitidos por seus familiares. Neste sentido, a família deve ser estável emocionalmente para atingir o desenvolvimento afetivo de seus descendentes, além de fortalecer os vínculos familiares para edificação da sua estrutura, evitando um rompimento de laços afetivos quando surgirem fatores que possam desestruturála.

A convivência familiar e comunitária é um direito assegurado no art. 19 do Estatuto da Criança e do Adolescente e na atual Constituição Federal Brasileira no art. 227. Além disso, o PNFCC visa traçar estratégias e diretrizes para que esse direito seja assegurado de fato para todas as crianças e adolescentes. Tal plano reconhece a convivência familiar e comunitária como fundamental para o desenvolvimento da criança e do adolescente, que não podem ser concebidos de modo dissociado de sua família, do contexto sócio-cultural e de todo o seu contexto de vida (PNFCC 2006, pg. 29). 
Desse modo, preconiza-se que essa convivência familiar deve ser saudável para o bom desenvolvimento de seus membros. Porém, a mesma pode mudar em face de alguns fatores gerados com o contexto social na qual a família está inserida. As regras familiares podem entrar em conflito com o contexto social e ir ao desencontro das ideologias hegemônicas ou modelos diferentes, ou até mesmo ferir "idéias de cidadania dos próprios indivíduos que compõe a família" (AMAS, 2005)

\subsubsection{O perfil das famílias que tiveram seus filhos abrigados}

Por meio das pastas dos sujeitos pesquisados foi possível observar e analisar a realidade social de oito famílias:

Tabela 1. Perfil das famílias dos sujeitos abrigados

\begin{tabular}{|l|l|l|l|l|l|l|}
\hline Família & Ocupação & Habitação & Escolaridade & Alcoolismo & Dificuldades & Região \\
\hline I & $\begin{array}{l}\text { Desemprega } \\
\text { dos }\end{array}$ & Barraco & Analfabeta & Não & $\begin{array}{l}\text { Trabalho e } \\
\text { habitação }\end{array}$ & Gama \\
\hline II & $\begin{array}{l}\text { Desemprega } \\
\text { da e/ou } \\
\text { aposentado }\end{array}$ & 01 cômodo & Analfabeta & Sim & $\begin{array}{l}\text { Alcoolismo, } \\
\text { habitação, } \\
\text { trabalho } \\
\text { vínculo afetivo }\end{array}$ & e \\
\hline III & $\begin{array}{l}\text { Aposentado } \\
\text { Varjão }\end{array}$ & Própria & Não se sabe & Sim & $\begin{array}{l}\text { Psicológicas, } \\
\text { alcoolismo e } \\
\text { melhorias na } \\
\text { casa. }\end{array}$ & Ceilândi \\
a
\end{tabular}




\begin{tabular}{|l|l|l|l|l|l|l|}
\hline VII & $\begin{array}{l}\text { Desemprega } \\
\text { dos }\end{array}$ & $\begin{array}{l}\text { Sem } \\
\text { habitação }\end{array}$ & Não se sabe & Sim & $\begin{array}{l}\text { Alcoolismo e e } \\
\text { drogas, } \\
\text { habitação, } \\
\text { trabalho }\end{array}$ & \\
\hline VIII & $\begin{array}{l}\text { Desemprega } \\
\text { dos }\end{array}$ & Barraco & Não se sabe & Sim & $\begin{array}{l}\text { Alcoolismo } \\
\text { drogas, } \\
\text { habitação, } \\
\text { trabalho } \\
\text { vínculo afetivo }\end{array}$ & e \\
\hline
\end{tabular}

Elaboração própria. Julho, 2009

No quesito ocupacional, os dados traduzem a situação dos genitores, a qual não é diferente da maioria da população brasileira. Observou-se que apenas uma das oito famílias tinha os genitores inseridos no mercado formal de trabalho, mas com um rendimento muito ínfimo, incapaz de suprir todas as necessidades da família. Havia apenas dois genitores que tinham renda oriunda de aposentadoria, mas a genitora estava desempregada. As famílias que não estavam inseridas no mercado de trabalho sobreviviam apenas de trabalhos esporádicos "bicos" - ou de algum programa do governo e/ou ajuda da própria instituição de abrigamento.

Em relação à questão habitacional, nota-se que a maioria das famílias está em situações precárias de moradia, necessitando construir quartos e banheiros, além de melhorias nas instalações das casas. Os barracos em geral são feitos de madeira nas piores condições de insalubridade e higiene. Além disso, nota-se que uma das famílias é moradora de rua, sem nenhuma condição de habitação.

Quanto à escolaridade, os dados mostram que 50\% dos genitores têm um nível escolar muito baixo, não completando sequer o nível fundamental. Quanto às outras famílias, não foi possível, por meio dos dados, verificar o nível de escolaridade. Porém, diante da realidade das famílias, deduz-se que o nível de escolaridade destas não é muito elevado.

Em relação às dificuldades, observou-se que, majoritariamente, as famílias têm dificuldades financeiras, em razão do desemprego manifestado em seis delas. E, mesmo quando inserida no mercado de trabalho, não aufere renda suficiente que proporcione condições favoráveis aos cuidados e suporte aos seus membros. Observa-se que o alcoolismo é predominante na maioria dos ambientes das famílias pesquisadas, o que dificulta a superação de outras dificuldades no lócus familiar. 
Cabe ainda ressaltar acerca da constituição familiar, onde a separação dos genitores está presente na maioria, constituindo $62 \%$ das famílias monoparentais. O restante havia constituído novamente a família com outro(a) companheiro(a). Observa-se, ainda, que a maioria das crianças, antes de ser abrigada, morava com as genitoras que não recebiam nenhuma ajuda dos genitores para ajudar nas despesas dos filhos.

\subsubsection{Fatores que influenciaram na ruptura do vínculo familiar}

Como analisado, não há um modelo familiar ideal que consiga dar conta da complexidade dos fenômenos que emergem dessa instituição em contato com o contexto social. Entretanto, autores como Kaloustian e Ferrari (1994, apud GOMES \& PEREIRA, 2005) ressaltam o reconhecimento dessa instituição familiar para a consolidação da sociedade. Segundo estes autores, é na família que os membros recebem os aportes afetivos e materiais necessários ao seu desenvolvimento e bem-estar, além de receberem a educação informal e formal, aprendendo valores éticos, morais e culturais, e principalmente a ser solidários.

A família atua diretamente na construção da personalidade e do caráter de seus indivíduos, constituindo a base fundamental da sociedade, uma vez que é o principal agente socializador de seus membros. Contudo, essa instituição familiar deve ter condições sociais, afetivas, econômicas e psicológicas para dar conta dos problemas sociais que surgem no bojo da sociedade. Sob esta perspectiva, Petrini (2003, apud GOMES \& PEREIRA 2005) assegura que as situações de vulnerabilidades sociais estão vinculadas às condições precárias que dificultam ou impedem as famílias a proporcionarem, de modo satisfatório, recursos materiais, afetivos e psicológicos, prejudicando a sustentação e manutenção dos vínculos familiares.

\subsubsection{Fatores socioeconômicos}

Tendo como base a análise feita por Carvalho e Almeida (2003), sobre a instituição familiar nos anos 90, verificou-se que a família sofreu grandes transformações a partir desse período. Um dos pressupostos para a o surgimento dessas metamorfoses foi a crise, eminente nessa época, que aliada à desestruturação interna familiar, atingiu e modificou as funções da família. Segundo estas autoras, essa instituição familiar, quando atingida por esses dois processos, comprometeu sua capacidade de dar assistências aos seus membros e de protegêlos socialmente. 
Apesar de a instituição familiar possuir grande capacidade de mutação e adaptação às transformações da sociedade, caso ela seja atingida pela vulnerabilidade social e não obtenha apoio de políticas sociais efetivas que visem aliviar suas extremas carências, essa instituição pode perder gradativamente sua capacidade de funcionar, como mecanismo de proteção social de seus indivíduos (CARVALHO \& ALMEIDA, 2003).

Os dados da pesquisa trazem algumas situações, como mostrado no perfil das famílias pesquisadas, em que a maioria é pobre, sem moradia e sem trabalho que lhes garantam a sua sobrevivência e a de seus filhos, e dificilmente encontra meios para superar as condições desfavoráveis.

Neste sentido, esses dados revelam que a maioria das famílias não tem condições econômicas que para garanta a sobrevivência dos seus membros. Muitas vezes, a família é obrigada a solicitar o abrigamento dos filhos por não ter um teto para acolher os filhos e nem alimentos para suprir suas necessidades. Como no exemplo da família I, onde já havia feito um abrigamento dos filhos, mas a situação sócio-econômica permanecia em extrema miséria $e$ teve que abrigar novamente outros filhos (Rel. Inf. da Família I). São genitores que sem emprego ou outra fonte de renda não conseguem ter moradia, alimentos básicos e remédios (subsídios mínimos) para garantir a sobrevivência dos seus dependentes, e que acaba por gerar a insegurança alimentar ${ }^{5}$ em toda família.

Sem o apoio do Estado, a única alternativa para garantir sua sobrevivência e dos filhos foi deixá-los abrigados. Situação esta que corrobora com a tese de Petrini (2003, apud GOMES \& PEREIRA 2005), a qual defende que famílias em situações precárias e vulneráveis socialmente não dão conta de garantir o sustento dos filhos. Segundo Gomes e Pereira, "a pobreza, a miséria, a falta de perspectiva de um projeto existencial que vislumbre a melhoria da qualidade de vida, impõe a toda família uma luta desigual e desumana pela sobrevivência." (p.360).

Esse estado de pobreza e miséria foi intensificado com a reestruturação produtiva, que trouxe profundas modificações no mundo do trabalho, como a introdução de inovações tecnológicas e a constituição das formas de acumulação flexível (ANTUNES, 2005). Ainda, como se sabe, o mercado não gera empregos para absorver toda a população, que sem renda é levada a um estado de indigência social.

\footnotetext{
5 A insegurança alimentar é a incerteza da população em acessar alimentos suficientes para uma vida saudável, essa incerteza está ligada diretamente como o poder aquisitivo, ou seja, a renda disponível das famílias para compras os alimentos (Hoffmann, 1995).
} 
Esse é o cenário que temos a partir dos anos 90, momento em que tal reestruturação, alinhada à gestão neoliberal da economia brasileira, privilegiou uma política restritiva, resultando no desemprego estrutural, precarização e perdas salariais, bem como a perda de benefícios trabalhistas, de forma que milhões de trabalhadores foram alijados dos seus direitos adquiridos.

É nesse contexto que se encontram as famílias, exclusas do mercado de trabalho, sem renda e sem apoio de políticas públicas eficientes. Situando-se na pobreza e no estado de vulnerabilidade social, como apresentado em um Acompanhamento Social: A única fonte de renda da família é trabalhos esporádicos feitos pelo companheiro da genitora. Este mesmo documento revela que essa família não recebe nenhum benefício governamental (AC. S. da Família I).

A tendência dessas famílias circunscritas nessa situação acima apresentada é participar cada vez mais da degradação social, onde os indivíduos são levados ao estado de miserabilidade em consequiência da falta de trabalho e da falta de renda. Tudo isso impossibilita aos indivíduos manter suas moradias em boas condições, situação observada no Relatório Informativo: Mora em barraco cedido em troca de cuidados de outro lote de um Senhor. O barraco é feito de pedaços de telhas e madeira, o piso é de terra, não há esgoto, água encanada e nem banheiro (usa o mato, sic!) (A. S. Família I).

Nessa conjuntura, percebe-se ainda a falta de escolaridade dos genitores, constituindose como um fator impeditivo para a mobilidade social dos membros dessas famílias pobres, que tem que deixar de estudar muito cedo para trabalhar. A maioria dos indivíduos acaba por abandonar a escola, prejudicando a ampliação do conhecimento, único meio para conseguir a cidadania e conseqüentemente a mobilização social. Pois, sem a educação, o indivíduo é alijado dos seus direitos, distanciando-se de sua cidadania e da sua emancipação.

Como mostrado no perfil das famílias pesquisadas, o nível de escolaridade é muito baixo, dificultando a conquista de um emprego que lhes garantam boa remuneração, uma vez que o mercado de trabalho está cada vez mais exigente. Ainda, o trabalho desvalorizado, a pobreza e a falta de conhecimento implicam na ausência de perspectivas, deixando o indivíduo inerte e dificultando sua ascensão social. Desse modo, a família não consegue meios que lhe possibilite modificar suas condições socioeconômicas desfavoráveis, para que assim os filhos possam ser reintegrados em suas famílias.

Então, pode-se concluir que as famílias de classe baixa são marcadas pelas expressões da questão social, como a pobreza extrema, o desemprego, o aviltamento salarial, a falta de habitação, a falta de escolarização e de assistência social. Tudo isso as levam a um círculo de 
pobreza, de modo que as vítimas mais prejudicadas dessa injustiça social são as crianças e adolescentes, que ficam ameaçados e com seus direitos violados.

\subsubsection{Fator Afetivo}

O afeto é um elemento de extrema importância no que diz respeito ao convívio entre as pessoas. No contexto familiar, isso pode ser visto na aproximação e no cuidado envolvido que os pais têm para com os seus filhos. Discutindo sobre o comportamento de apego, Bowlby (1982) afirma que esse é imprescindível para o desenvolvimento da personalidade do indivíduo, pois a relação afetiva entre a mãe e o bebê, cercada de compreensão, sensibilidade e aceitamento do comportamento da criança, proporcionará uma estabilidade e autoconfiança desta quando adulto.

Ainda este autor afirma que o vínculo afetivo é a relação de atração que os indivíduos sentem uns pelos outros, porém essa vinculação afetiva se mantém apenas quando se perdura essa proximidade entre esses indivíduos (BOWLBY,1982;). Weber (2004) contribui para este entendimento, mencionando que é na relação parental, ou seja, no processo de interação entre mãe e filho, que se garante a construção desse vínculo afetivo. Desse modo, cabe ressaltar aqui a importância de trabalhar no sentido de manter os vínculos entre os pais e filhos abrigados, de modo que com as visitas e a interação entre eles possa se fortalecer as relações de afeto.

Contudo, Badinter apud Fávero (2001) salienta que o amor materno é uma construção sócio-cultural, não é um sentimento inato à espécie humana, pois depende de condições sociais, econômicas e históricas. Nesta mesma linha de pensamento, Gomes e Pereira (2005) afirmam que o estado de privação de direitos leva à descrença do ser humano e assim, ao afastamento do sentimento afetivo, que em contrapartida adota o sentimento de separação. Depreende-se dessa afirmação que na medida em que a família não consegue prover as condições básicas dos seus membros, as relações interativas poderão ser fragilizadas.

Analisando os dados da pesquisa, verificou-se que em algumas famílias dos sujeitos pesquisados havia indícios de forte ligação afetiva entre genitores e seus filhos, porém, em outras famílias, os vínculos afetivos foram enfraquecendo com o passar do tempo, de modo que contribuiu para a ruptura do vínculo familiar, como aponta a literatura (WEBER, 2004). Contudo, havia famílias em que não existia nenhum vínculo afetivo entre genitores e filhos abrigados. 
É importante ressaltar o quadro em que estão inseridas aquelas famílias cujos vínculos afetivos não existem. São famílias que se encontram em uma situação socioeconômica lamentável, com habitação precária e insalubre. São famílias moradoras de rua e/ou desempregados, com envolvimento no alcoolismo e nas drogas psicotrópicas. Acerca dessa situação, Gomes e Pereira (2005) afirmam que pode desencadear um sentimento de descrença nos indivíduos, quando estes não acreditam que sua vida pode melhorar, assim adotam atitudes danosas para fugir de sua realidade. Como foi o caso de uma genitora extremamente pobre e viciada em drogas: A genitora tomou duas cartelas de remédio para o coração, com a intenção de se suicidar, devido às dificuldades que estava passando (A. S. Família VIII).

Percebe-se mais uma vez, diante dessa situação, a influência da pobreza e da miséria nos rompimentos dos laços familiares. Famílias que não têm meios para superar as mazelas sociais podem perder o sentido do afeto e até mesmo da importância da vida. Os vínculos enfraquecidos ou perdidos contribuem para o afastamento entre genitores e seus filhos, dificultando uma futura reintegração familiar.

Outro exemplo foi o caso de duas abrigadas em que se tentou a reintegração familiar, visto que o genitor havia superado sua dificuldade com o alcoolismo. Contudo, uma das abrigadas não tinha vínculos afetivos com o genitor, pois este quase não as visitava enquanto abrigadas, o que implicou na fragilização dos vínculos afetivos.

Paralelamente, foi averiguado que na maioria das famílias em que os vínculos afetivos eram fortes, as condições sociais eram melhores que aquelas que tiveram os vínculos fragilizados. Contudo, não há nenhuma intenção em fazer uma generalização apenas com esses dados, mas ressaltar que em muitos casos de abrigamentos a ruptura dos laços afetivos pode estar diretamente ligada à falta de condições socioeconômicas das famílias, que ainda pode ter como um agravante o uso de álcool e drogas.

\subsubsection{Fatores Culturais}

Mudanças culturais têm ocorrido em relação ao papel da mulher com o impacto da reestruturação produtiva. A função de chefe de família, outrora exclusivamente masculina, passa a ser uma constante para muitas mulheres. Essas famílias, monoparentais, na maioria, são constituídas apenas por mulheres e filhos. De acordo com Borges (2006) a causa desse fenômeno pode ser em virtude da 
elevação do desemprego e as perdas salariais de homens adultos vêm contribuindo para acelerar a desconstrução do papel do homem provedor, processo que, não raro, resulta em conflitos intrafamiliares, inclusive na violência contra mulher e filhos, na dissolução do vínculo conjugal ou, simplesmente, na fuga das responsabilidades da paternidade.

Em nota ao Correio Brasiliense, a socióloga Renata Limeira ${ }^{6}$ explica que a pobreza, a miséria, o abandono e a prisão afastam os homens de suas casas, incumbindo toda responsabilidade para mulheres - donas de casa. A mulher fica sobrecarregada, pois exerce sua função de cuidados maternos e, ainda, passa a assumir a função de provedora, que outrora era essencialmente masculina, deixando-a mais vulnerável socialmente (RABELO, 2008). Carvalho e Almeida (2003) apontam que a probabilidade desse tipo de família ser pobre ou muito pobre é muito alta, uma vez que no mercado de trabalho há uma acentuada diferença salarial de gênero.

$\mathrm{Na}$ pesquisa foram identificadas duas famílias nesses moldes, constituída apenas pela genitora e filhos. Na primeira, a genitora arca com a despesa sozinha da casa, além dispensar cuidados e afeto aos filhos. Os rendimentos que aufere são insuficientes para garantir as condições necessárias para sua sobrevivência e dos filhos, inclusive na casa onde mora verificou-se, por meio dos relatórios, que as condições de habitação são precárias (Rel. Inf. Famílias IV, e VI), situação esta que corrobora com a afirmação supracitada de Carvalho e Almeida (2003). A outra família também tem como chefe de família a genitora, que recebe auxílio financeiro para cuidar do filho. Entretanto, esta por ser alcoolista acaba por não ter condições psicológicas para manter um vínculo afetivo saudável com o filho.

Ainda, verifica-se nesse modelo familiar que a responsabilidade que era do pai passa a pertencer à mãe, sobrecarregando-a e esgotando-a, sem condições de oferecer afeto e toda atenção de que as crianças precisam, enfraquecendo o seu laço afetivo maternal, manifestando assim a "síndrome da casa vazia", descrita por Moura (1996, apud ARPINI \& QUINTANA, 2003), onde as crianças se aproximam do mundo da rua. No entanto, também se verificou que se a ligação é mais forte com o genitor, as crianças poderão ir à sua busca, como é revelado por um dos Relatórios Informativos, em que a genitora disse que a filha sente muita falta do pai e que fugiu por conta disso, pois tem mais vínculo com o pai do que com ela (A. S. Família IV).

Percebe-se que a relação familiar é prejudicada em função dessa nova conjuntura, pois para trabalhar e educar os filhos a genitora, agora sozinha, revela algumas situações de 
impotência e medo, como mostram algumas anotações no Relatório Informativo da família: $A$ genitora teme por não conseguir dar limites para os dois filhos mais velhos, que são mais agitados. Reafirmou a necessidade de realizar acordo com o genitor para que o mesmo assuma os filhos (A. S. Família IV).

Diante dessa situação, percebe-se que a vinculação afetiva é muito importante para a organização familiar, mas quando a família se modifica internamente e as responsabilidades recaem sob apenas um responsável, que até antes as dividia com alguém, a relação familiar passa a ser conflituosa e tende a se fragilizar e a romper-se. Para Sarti (1994) a explicação nesse caso pauta-se por ser uma genitora jovem, chefe de família, cuja responsabilidade pela manutenção da casa, e, ao mesmo tempo, pela administração da casa, acaba por não conseguir gerenciar as dificuldades oriundas do estado de pobreza em que se encontra.

Ademais, as mudanças culturais em relação às regras e costumes familiares também podem ser outros fatores que podem gerar conflito interno na estrutura familiar. Sabe-se que os indivíduos possuem características, opiniões e atitudes particulares que podem variar de ser para ser. Essas discrepâncias entre personalidades podem gerar conflitos no ambiente familiar, acarretando divergências e até mesmo enfraquecimento de vínculos. A criança que não teve o convívio familiar acaba se distanciado dos costumes, dos valores éticos e moral da família, criando sua própria identidade, diferente da sua referência familiar, podendo gerar conflitos quando de volta à sua família.

Essa situação foi verificada quando uma jovem, que passou muitos anos em uma Instituição de abrigamento, não teve contato íntimo com os seus familiares e quando de volta para casa, adotou comportamentos e atitudes desaprovadas por aqueles, de modo que a relação entre a jovem e sua família ficou fragilizada.

$\mathrm{Na}$ pesquisa, também foram encontrados outros fatores culturais que podem influenciar na naturalização e na perpetuação de certos modos de vida. A violência doméstica contra mulher é uma realidade em uma das famílias pesquisadas. Esse tipo de violência pode ser transmitida numa cultura intergeracional paternalista em que a mulher se submete ao homem por se achar um ser frágil e não acreditar ser capaz de sustentar a si e seus filhos. Por não conseguir sua independência e por se sentir impotente para procurar meios para mudar sua condição de vida, submete-se à violência para garantir o seu sustento, como encontrado em alguns dos relatos: A genitora é agredida verbalmente e fisicamente pelo companheiro, tendo um relacionamento conflituoso, dizendo que vive com ele por depender financeiramente (Rel. Inf. Família I). 
Esta passagem revela a influência da cultura no âmbito familiar em que a mulher se submete a atos degradantes da pessoa humana, por não exercer sua independência financeira. Sem forças e meios para emancipar-se, vive uma relação em que a intolerância e a violência podem se perpetuar na história, naturalizando-se e difundindo entre os membros da família.

Desse modo, percebe-se que as mudanças culturais também podem influenciar direta ou indiretamente no enfraquecimento ou até mesmo no rompimento dos laços familiares.

\subsubsection{Os Fatores Simbólicos e Psicológicos}

A identidade leva ao conhecimento singular do indivíduo, o qual exprime seus afetos, motivações que são apreensões a partir das relações com seus referentes. A referência familiar é um pressuposto para que os indivíduos constituam a sua família, a partir de uma identidade adquirida no lócus familiar. Sem o convívio familiar torna-se difícil para o homem aprender valores, regras e manter o bom convívio social.

Identificou-se na pesquisa uma família cujos genitores passaram a infância e adolescência numa Instituição de abrigamento. $\mathrm{O}$ genitor foi abrigado ainda quando criança, visto que perdeu os pais muito cedo. Para este, o símbolo da representação familiar ficou prejudicado, pois passou sua infância e adolescência numa Instituição, sem referência familiar. Essa falta do convívio familiar não possibilitou ao mesmo que adquirisse noções acerca da importância familiar para o desenvolvimento saudável dos filhos. Dessa forma, acabou por reproduzir o ciclo do abrigamento infantil, uma vez que não consegue dar conta do papel de pai para retirar do abrigo o seu filho. Assim, sem esta referência, não consegue manter os cuidados necessários e básicos para o desenvolvimento saudável da criança, dificultando o retorno do filho ao convívio familiar.

Outro problema verificado nesse estudo diz respeito à família que sofre com problemas psicológicos. O comprometimento mental foi determinante para que os filhos permanecessem no abrigo, mesmo quando superada as condições desfavoráveis que levaram ao abrigamento das crianças, pois essa família não dispensava os cuidados necessários para o desenvolvimento saudável dos filhos. Além disso, não conseguia gerenciar os seus recursos para manutenção básica da família. Entretanto, apesar do comprometimento mental de toda a família, a ruptura familiar não fragilizou os vínculos afetivos que, ao contrário, se manifestavam muito fortes entre os membros familiares.

Por fim nota-se que a complexa e dinâmica rede de interações da família envolve aspectos sociais, econômicos, afetivos, simbólicos, culturais e psicológicos, os quais exercem 
grande influência na ruptura dos laços familiares, bem como podem dificultar a reintegração familiar. São fatores que não se restringem apenas ao aspecto biológico, como problemas mentais, mas que emergem de várias dimensões da relação com o contexto social, como a miséria, pobreza, o desemprego, falta de habitação, o alcoolismo, entre outros. 


\section{Capítulo III}

\section{A Violência Doméstica Contra Crianças e Adolescentes como fator de Abrigamento}

\subsection{A Violência Doméstica e Intra-Familiar contra Crianças e Adolescentes}

No contexto da sociedade brasileira, milhares de famílias se esforçam para proteger seus filhos. Contudo, existem traços culturais, mesmo que em diferentes graus, de relações familiares adultocêntricas, machistas, autoritárias, que as levam a ser mais ou menos violentas (FALEIROS \& FALEIROS, 2008). De acordo com Azevedo \& Guerra (1989, apud BARROS, 2005), a violência contra crianças e adolescentes é democrática: atinge todas as raças, todos os países e todas as classes sociais.

O termo violência tem origem do latim violentia, significa a ação de violentar abusivamente contra o direito natural, produzindo coação sobre determinado indivíduo, obrigando-o a realizar algo contra a sua vontade (CLIMENE \&BURALLI, apud BALISTA et al., 2004).

Para explicar a violência, Faleiros \& Faleiros (2008) utiliza a teoria do poder. De acordo com estes autores, o poder implica em uma relação, mas nem sempre está associado a uma relação de violência. Apenas se configura como violento quando alguém exerce uma relação de força (coação) sobre outro, visando obter vantagens e alcançar objetivos.

Neste sentido, a violência contra crianças e adolescentes se configura numa relação vertical, a qual é exercida pelo ser mais forte que domina o mais frágil, abstendo este último dos seus direitos e de sua identidade. Minayo (2001, apud FALEIROS \& FALEIROS, 2008) ${ }^{7}$ define a violência contra crianças e adolescentes como

[...] todo ato ou omissão cometido pelos pais, parentes, outras pessoas e instituições capazes de causar dano físico, sexual e/ou psicológico à vítima. Implica, de um lado, uma transgressão no poder/dever de proteção do adulto e da sociedade em geral e, de outro, numa coisificação da infância. Isto é, uma negação do direito que crianças e adolescentes têm de serem tratados como sujeitos e pessoas em condições especiais de crescimento e desenvolvimento.

\footnotetext{
${ }^{7}$ MINAYO, M. C. S. (Org). Pesquisa Social: teoria, método e criatividade. Petrópolis: Vozes, 2001.
} 
Este conceito de Minayo acerca da violência contra criança e adolescentes é o mais apropriado e será adotado para fins de análises deste estudo.

A violência contra crianças e adolescentes pode ser configurada como doméstica ou familiar. Faleiros \& Faleiros (2008) chamam a atenção para a distinção entre essas duas modalidades, visto que esses termos não são sinônimos. A primeira refere-se ao ambiente físico em que se manifesta o ato de violência, podendo atingir os familiares ou aqueles que trabalham no lócus familiar. Enquanto que na segunda, o agressor e agredido possuem uma relação de parentesco.

De acordo com esses autores, todas as pesquisas nacionais e internacionais indicam os familiares como os maiores agressores desse segmento infanto-juvenil, ato justificado como uma forma de educá-los. A mãe é apontada como aquela que pratica a violência física, e psicológica, enquanto que e o pai a violência sexual (FALEIROS \& FALEIROS, 2008).

No art. $5^{\circ}$ do ECA é estabelecido que nenhuma criança ou adolescente será sujeito de qualquer forma de negligência, discriminação, exploração, violência, crueldade e opressão, punido na forma da lei qualquer atentado, por ação ou omissão, aos seus direitos fundamentais. Ainda no seu art. 18 preceitua que é dever de todos velar pela dignidade da criança e do adolescente, pondo-os a salvo de qualquer tratamento desumano, violento, aterrorizante, vexatório ou constrangedor (ECA, 1990).

Entretanto, a instituição familiar, lugar em que a criança e o adolescente deveriam estar seguros, é o ambiente em que essa população vem sofrendo os mais diversos atos de violência, principalmente por aqueles que deveriam cuidar e dar carinho para o seu pleno desenvolvimento.

\subsubsection{Tipos de violência contra crianças e adolescentes}

A violência contra crianças e adolescentes tem diversas classificações, as mais comuns são violência física, psicológica e sexual. Faleiros \& Faleiros (2008) trazem diversas formas em que a violência é concebida contra o segmento infantil-juvenil. A violência estrutural é a expressão das desigualdades sociais e econômicas que vitimizam milhares de crianças e adolescentes pobres. A violência simbólica é o exercício e divulgação de mitos, símbolos, imagens, mídia e construções sociais fundados numa hierarquia que visa à discriminação, humilhação e exclusão. Ainda, a imposição de regras, crenças e valores, coagindo o outro a consentir. 
Outra forma de violência é a institucional, que está associada às condições dos locais onde a mesma ocorre, podendo ser manifesta pela violência física, psicológica e/ou sexual. A negligência profissional também é uma violência institucional em que há descaso pelo profissional em relação a sinais que podem levar a violências mais graves (FALEIROS \& FALEIROS 2008).

A violência física é a utilização da força física provocando lesões, queimaduras, traumatismos, mordidas, arranhões, convulsões, entre outros, podendo até levar à morte. $\mathrm{O}$ indivíduo que sofre violência física também sofre psicologicamente, pois nesse tipo de agressão a criança está envolta de medo, espanto e terror. Diferentemente da violência física, tem-se a violência psicológica, que não deixa marcas visíveis, entretanto destrói a autoimagem, alterando o comportamento do violentado (Faleiros \& Faleiros 2008) e deixando cicatrizes na alma da pessoa.

Outros tipos de violências domésticas como a negligência, o abandono, maus tratos e violência sexual serão abordados com mais profundidade, em termos conceituais, visto que foram os mais ressaltados nas pastas documentais das crianças e adolescentes pesquisados.

\subsubsection{Negligência e Abandono}

Estes dois tipos de violência têm uma similaridade entre si: são manifestados por atos de omissão, nos quais os responsáveis por crianças e adolescentes não fornecem a estes nutrientes nem suportes afetivos consoantes ao que necessitam para o seu desenvolvimento biopsicossocial de forma saudável (FARINATTI, 1993, apud SILVA, 2002). Porém, a negação desses cuidados e a negação de proteção podem ocorrer pela dificuldade da interação entre os entes da família, o ambiente físico, o simbólico e a sociedade (idem, ibidem).

Barros explica que "as situações de efetivo abandono são o ponto de culminância de uma seqüência de abandonos familiares, que vão dos aspectos mais objetivos ligados a questões financeiras a outros mais subjetivos, também relacionados aos vínculos afetivos" (2005, p. 57). A negligência e o abandono, como visto em Farinatti (1993, apud SILVA, 2002), tem uma relação muito similar, no sentido em que quando há a omissão de cuidados com o indivíduo dependente, pode constatar-se a negligência e o abandono ao mesmo tempo.

Entretanto, Rodrigues e Carvalho (1998, p.65) alertam para que o quadro de negligência seja bem compreendido, no sentido de não culpar a família cujas ações não sejam intencionais. Assim, de acordo com essas autoras, a negligência 
consiste no fato de a família se omitir em prover as necessidades físicas e emocionais de uma criança ou adolescente. Configura-se no comportamento dos pais quando falham em alimentar, vestir adequadamente seus filhos, medicar, educar e evitar acidentes. Tais falhas só podem ser consideradas abusivas quando não são devidas à carência de recursos sócio-econômicos.

Do mesmo modo, Fuziwara (2004, apud VOLIC \& BAPTISTA, 2005) ${ }^{8}$ chama a atenção para a importância do uso correto do conceito de negligência na esfera judiciária. Visto que é comum a oposição do conceito desse termo entre os operadores de justiça e os diversos técnicos que auxiliam com os instrumentais técnicos - laudos e pareceres -, os quais subsidiam decisões judiciárias, podendo alterar a vida das pessoas, com as diferenciações acerca deste termo adotado. Esta autora salienta que deve existir uma normatização do conceito de negligência no âmbito jurisdicional, para que haja uma compreensão no mesmo sentido entre os técnicos e operadores de justiça, não prejudicando a relação entre os membros familiares que deveriam ter um suporte para não afastar os filhos de seus pais (FUZIWARA, idem).

A detecção da negligência, segundo Volic e Baptista (2005), se dá principalmente numa situação em que se configura dependência de cuidados materiais, psicológicas ou sociais, e na falta de proteção de um indivíduo para com outro, podendo variar a sua determinação no espaço, no tempo e de grupo para grupo.

Outros aspectos considerados como negligência são apontados por Barros (2005, p. 57), como "omissão de pais e responsáveis em prover as necessidades físicas e emocionais de uma criança ou adolescente. Pode ser percebida através de faltas constantes às aulas, de roupas rasgadas e sujas, de falta de higiene, entre outros sinais."

Faleiros \& Faleiros (2008, p. 34) apresentam outras formas e graus de negligências em que crianças e adolescentes vivenciam situações de abandono, privação e exposição a riscos:

\footnotetext{
o abandono (forma extrema); crianças não registradas; pais que não reconhecem sua paternidade; crianças "deixadas/entregues/dadas sem papel passado" a familiares, conhecidos ou mesmo desconhecidos; crianças "pingue-pongue", que circulam de "mão em mão" e que "não são de ninguém"; crianças e adolescentes que assumem responsabilidades de adultos (cuidam de si próprios e/ou de irmãos pequenos, assumem todas as tarefas domésticas, contribuem com a renda familiar e/ou se sustentam através da mendicância, trabalho infantil, prostituição); meninos e meninas de rua, sem controle ou proteção e expostos à violência familiar ou comunitária.
}

\footnotetext{
8 FUZIWARA, Áurea Satomi. Significados em disputa: Reflexão sobre a influência dos laudos técnicos dos assistentes sociais do judiciário paulista e das representações sociais nas jurisprudências que tratam de "negligência" no cuidado de crianças e adolescentes. São Paulo, PUC- SP, 2004.
} 
O reconhecimento desses aspectos e dos responsáveis que levam ao quadro de negligência é essencialmente importante para garantir a vida e a sobrevivência do segmento infanto-juvenil, bem como a sua permanência na família. Desse modo, ao identificar as necessidades e responsabilidades - caso a família esteja no estado de vulnerabilidade social -, é necessário que ela seja amparada e inserida em programas sociais que visem à superação desse quadro, como é estabelecido no Estatuto da Criança e do Adolescente, na seção I, parágrafo único: Não existindo outro motivo que por si só autorize a decretação da medida, a criança ou o adolescente será mantido em sua família de origem, a qual deverá ser obrigatoriamente incluída em programas oficiais de auxílio (ECA, 1990).

\subsubsection{Maus tratos}

Essa modalidade de violência tem se manifestado, historicamente, através de práticas corporais e infanticídios. A adoção de castigos e surras imoderadas é usada como uma maneira de corrigir a criança, e, muitas vezes de extravasar momentos de tensão e desgosto, o que danifica a estrutura física e psicológica de adolescentes e crianças.

Os maus tratos têm uma gama de significados. Amaro (2006, p. 227-228) os considera como:

negligência, tortura, pressão psicológica, coação, humilhação, punição cruel, privação de liberdade, trabalho infantil perigoso, ilegal ou insalubre, estimulação sexual, exploração sexual (prostituição infantil), realização ou tentativa de penetração sexual (oral, anal ou genital)

De acordo com Amaro (2006), aproximadamente 6.500 crianças, apenas em 2002, morreram vítimas de violência no Brasil. Os maus tratos são um dos fenômenos que mais acometem crianças e adolescentes em todo país. Afirma ainda que esse tipo de violência não se restringe apenas no espaço doméstico, mas se amplia para outra esfera, a governamental, cujo governo não oferece condições suficientes para que as famílias pauperizadas saiam das condições de subcidadania.

É muito importante desvendar quando a criança ou o adolescente são vítimas de maus tratos, principalmente o sexual, pois segundo Saffioti (1997, apud AMARO, 2006), a criança quando sofre violência sexual mergulha em sentimentos de culpa e vergonha que, somados ao silêncio, à falta de auto-estima, ao medo, à depressão, entre outros fatores, podem levar a 
vítima a entrar numa "prisão" onde o suicídio pode significar a única saída para este sofrimento.

Assim, é importante notar algumas características manifestadas por crianças vítimas de maus tratos físicos e sexuais, visto que identificadas a tempo, pode impedir que o sofrimento se prolongue. Amaro relata algumas das expressões manifestadas por esse segmento vítima de violências. Dentre elas, a criança e o adolescente podem apresentar estados depressivos, manifestações de desejo de morte, regressão na linguagem e no comportamento, distúrbio do sono, expressiva baixa no aproveitamento escolar, erotização das relações de afeto e condutas anti-sociais, entre outras (2006, p. 234-235).

Além disso, Winnicott (1999, apud AZOR \&VECTORE, 2005) aponta que os maustratos na infância são prejudiciais a esse segmento infantil, acarretando sentimentos de insegurança e atrasos no desenvolvimento psicobiológico.

\subsubsection{Violência Sexual}

A violência sexual contra crianças e adolescentes é um fenômeno que independe de raça, credo, classe ou cultura. Os agressores situam-se em diferentes classes ou grupos sociais. Esse tipo de violência é mais comum acontecer no ambiente doméstico, porém mais difícil de ser identificado, uma vez que acontece no espaço privado e utiliza-se a coação ou a aliciação desse segmento infanto-juvenil para a prática do crime.

A violência sexual, de acordo com Faleiros e Faleiros (2008, p 39) é

\footnotetext{
o abuso delituoso de crianças e adolescentes, em especial de sua sexualidade, negando, inclusive, o direito das crianças e adolescentes a sua sexualidade em desenvolvimento. É considerada um crime na nossa legislação. O poder arbitrário do adulto agressor sobre as crianças e adolescentes desestrutura a identidade da pessoa vitimada, caracterizando-se como um comportamento perverso.
}

Várias são as formas da manifestação da violência sexual, podendo ser através de contato físico, incluindo carícias não desejadas, penetrações oral, vaginal ou anal, com o pênis ou até mesmo com objetos, masturbação forçada etc.; ou sem contato físico, com a exposição obrigatória a material pornográfico, exibicionismo e uso de linguagem erotizada em situação inadequada (FALEIROS \& FALEIROS, idem).

A violência sexual atinge milhares de crianças, desde zero ano de idade até mesmo os adolescentes. São indivíduos que necessitam de proteção e cuidados, mas que ao contrário são submetidos diariamente a conviver com esse tipo de agressão, por muitos anos. A dificuldade 
em descobrir esse crime e saber a quantidade concreta dessas vítimas é muito grande, uma vez que há um pacto de silêncio entre as pessoas, que acabam desconsiderando as evidências apresentadas pela vítima.

O abuso sexual é uma das formas da violência sexual de difícil evidenciação, muitas vezes praticado sem o emprego da força física - não deixa marcas visíveis, dificultando a sua comprovação (ARAÚJO, 2002; apud BARROS, 2005). O abuso intrafamiliar tem afetado mais o sexo feminino do que o masculino (FINKERLHOR, 1994, apud BARROS, 2005). Essa tendência pode ser explicada através de a cultura brasileira ainda ser machista, considerando normal os meninos iniciarem sua vida sexual mais cedo, encobrindo assim a violência sexual em relação ao gênero masculino.

Barros salienta que a violência sexual (ou abuso sexual) traz o aniquilamento desses indivíduos enquanto sujeitos, envolvendo-os por meio da coerção, persuasão ou até mesmo com o seu consentimento. Contudo, chama a atenção para que a justificativa utilizada nos atos contra os adolescentes de que os mesmos consentiram devem ser considerados como violência, pois a fase infanto-juvenil é considerada como fase peculiar de desenvolvimento, ou seja, ainda está adquirindo conhecimento e definindo suas escolhas para posteriormente efetivá-las (idem).

\subsubsection{O perfil da violência doméstica sofrida pelas crianças e adolescentes pesquisados}

O quadro abaixo revela o perfil da violência sofrida pelas crianças e adolescentes no lócus familiar, motivo este que mais influenciou na decisão judicial para o abrigamento infanto-juvenil. Foram pesquisadas 14 pastas de crianças e adolescentes cuja maioria era

filho da mesma genitora. Destaca-se que os dados documentais não permitiram o detalhamento das características dos tipos de violências sofridas pelos sujeitos pesquisados. 
Tabela 2. Perfil da Violência Doméstica dos sujeitos abrigados

\begin{tabular}{|c|c|c|c|c|c|}
\hline $\begin{array}{c}\text { Tipos de } \\
\text { violência }\end{array}$ & $\begin{array}{c}\text { Violência } \\
\text { Sexual }\end{array}$ & Negligência & $\begin{array}{c}\text { Maus } \\
\text { Tratos }\end{array}$ & Abandono & $\begin{array}{c}\text { Total de } \\
\text { crianças } \\
\text { pesquisa } \\
\text { das }\end{array}$ \\
\hline $\begin{array}{c}\text { Relação } \\
\text { violência/ } \\
\text { no de } \\
\text { vítima }\end{array}$ & 02 & 08 & 07 & 10 & $\mathbf{1 4}$ \\
\hline Sexo & F/M & F/M & F/M & F/M & ------- \\
\hline Agressor & Genitores & Genitores & Genitores & Genitores & ------ \\
\hline
\end{tabular}

Elaboração própria, julho, 2009.

*Houve casos em que a mesma criança foi vítima de duas ou mais violências, ao mesmo tempo.

A tabela mostra a relação violência/vítima observada durante o estudo. No universo de 14 crianças e adolescentes pesquisados, verificou-se que o abandono e a negligência foram os tipos de violência que mais atingiram aqueles sujeitos, implicando, ainda, nos principais motivos da aplicação da medida de abrigamento, seguido pelos maus-tratos e violência sexual. Ainda, deduz-se ao relacionar a totalidade da violência sofrida (27) por aqueles sujeitos pesquisados (14), mostrados nesta tabela, que algumas crianças foram vítimas de mais de um tipo de violência doméstica, pois a quantidade dessa violência é quase o dobro em relação à quantidade desses sujeitos. Ainda, ressalta-se que os genitores foram os principais violentadores desses sujeitos.

Analisando a relação desses tipos de violências e a condição social dessas famílias pesquisadas, verificou-se que o abandono e a negligência têm uma íntima ligação com a falta de condições financeiras dessas famílias - como apontado por Barros e Amaro (2005; 2006). Isso não significa que as famílias cuja situação social de extrema pobreza tenham uma relação direta com a violência contra esse segmento infantil. Contudo, a situação de miserabilidade somada ao alcoolismo, ao uso de drogas, à falta de comunicação, à baixa auto-estima e à vulnerabilidade da auto-imagem (Barros, 2005) pode desencadear conflitos familiares e gerar a violência doméstica contra crianças e adolescentes, como revelada nesta pesquisa.

Em relação à natureza do problema não foi possível caracterizar os tipos de violência de forma mais detalhada, mas pôde-se observar, por meio da análise do conteúdo, que na:

a) Família I houve dois abrigamentos. No primeiro em conseqüência de "total abandono da mãe" e no segundo pela "extrema miséria da família" (Rel. Inf.). Mas, durante o tempo de abrigamento, a genitora apresentou algumas 
características do abandono como a não visita aos filhos e falta de interesse em saber sobre a saúde, educação e no fortalecimento do vínculo familiar.

O abandono dos filhos por esta genitora pode estar ligado tanto a aspectos objetivos como questões financeiras, como a aspectos subjetivos - relacionados à fragilização dos vínculos afetivos, situação apontada em Gomes e Pereira (2005), em que o estado de privação leva à descrença do ser humano e, assim, ao afastamento do sentimento afetivo, adotando-se o sentimento de separação.

b) Na família II as crianças foram abandonadas pelos genitores, sendo recolhidas na rua. Estavam privadas de acesso à moradia, a alimentos, a educação, entre outros; esta situação decorreu em função do problema de alcoolismo apresentado pela genitora.

Percebe-se aqui não só o abandono das crianças pelos pais, mas também a ausência do Estado em oferecer suporte a essa família.

c) $\mathrm{Na}$ família III o abrigamento dos sujeitos deu-se pela negligência e maus tratos pelos genitores, que também faziam uso de álcool. Ainda o genitor sofria de problemas mentais.

Devido a esses problemas de saúde, o genitor não conseguia oferecer os cuidados materiais, orientação e condições de salubridades para o bom desenvolvimento dos filhos, que também tinham problemas mentais e eram maltratados pela genitora.

d) Na família IV as crianças foram encontradas na rua, pelo Conselho Tutelar, e não se sabia o endereço para voltar para casa, sendo abrigadas pelo motivo de negligência e maus tratos.

Acerca dessa situação ressalta-se que os motivos de negligência e maus tratos aplicados foram mal interpretados pelo Conselho Tutelar no ensejamento da medida de abrigamento desses sujeitos em especial, trazendo conseqüências para a família, como apontada em Fuziwara (2004, apud VOLIC \& BAPTISTA, 2005). A família que deveria ser incluída em programas para superação das condições de pobreza foi prejudicada ao ter seus filhos abrigados por um motivo que não se aplicava ao caso.

e) Na família $\mathbf{V}$ a criança foi abrigada pelo motivo de abuso sexual e cárcere privado pelo genitor. Entretanto, esses motivos não foram comprovados após o 
abrigamento, mas permaneceu abrigada por questões de pobreza do genitor, falta de trabalho que auferisse condições para assegurar a sobrevivência do abrigado.

f) Na família VI houve também aplicação da medida de abrigamento por causa de abuso sexual. Entretanto, neste caso foi constatado o emprego da violência pela genitora da criança. Ainda esta genitora tem problemas com o alcoolismo, que prejudica a superação das condições de vulnerabilidade social.

Como visto na tabela 1 , houve dois abrigamentos por motivo de violência sexual infantil, manifestados pelo abuso sexual dos genitores. Um dos casos foi cometido pela genitora em seu próprio filho, o que contraria algumas pesquisas sobre a temática, revelado em Faleiros \& Faleiros (2008), as quais mostram que a violência sexual é cometida pelo gênero masculino, contudo verificou-se que essa violência também é cometida pelo gênero feminino, mas é mais velada. Outra dificuldade é identificar o abusador, pois de acordo com Araújo (2005), o abuso pode não deixar marcas visíveis, sendo fundamental o depoimento da criança para confirmação do crime.

g) Na família VII o motivo se deu pelo abandono e negligência dos genitores, moradores de rua e dependentes de álcool e drogas.

Ressalta-se aqui, o que Barros aponta para as situações de efetivo abandono, visto que o seu ponto de culminância advém de uma seqüência de abandonos familiares e também do próprio Estado. Situação confirmada pelos dados analisados dessa família, que não tem nenhum suporte governamental do Estado.

h) Na Família VIII houve o abandono das filhas pela genitora, que também fazia uso de álcool e foi embora com um companheiro sem deixar informações sobre a sua localização.

Aproveitando o ensejo, é relevante mencionar, fazendo uso das palavras de Faleiros \& Faleiros (2008), que muitas vezes a negligência é considerada apenas responsabilidade das mães, prevalecendo a omissão de toda família, comunidade, sociedade em geral e o poder Público.

A partir dessas evidências empíricas pode-se comprovar que a negligência, o abandono e os maus tratos são os tipos de violências que mais levaram crianças e adolescentes ao abrigamento. Contudo, é importante ressaltar que a maioria das famílias não tem condições 
socioeconômicas favoráveis: seus provedores estão desempregados, possuem péssimas condições de habitações e, ainda, fazem uso de álcool e/ou drogas. Desse modo, infere-se que a violência doméstica contra essas crianças e adolescentes em situação de abrigamento pode ter sido influenciada pelas condições precárias da maioria das famílias e, ainda, exacerbou-se quando somadas a outros fatores, como o uso de álcool e drogas.

\subsection{A Suspensão do Poder Familiar e o Processo de Abrigamento Infanto-Juvenil}

O direito sobre os filhos era culturalmente conhecido como "pátrio poder", estabelecido no Código Civil Brasileiro, de 1916 - refletia-se numa lógica patriarcal dominante da época. A partir de 2002, com as novas configurações familiares, passou a ser chamado de Poder Familiar, abarcando, nessa concepção, o conjunto mãe-pai a respeito de seus direitos e deveres relativos aos filhos menores de dezoito anos. Esse poder visa garantir o direito e o dever de criar, educar e assistir aos filhos. De acordo com Roberto João Elias (apud, CECIF, 2005 p.51), o poder familiar é

o conjunto de direitos e deveres, em relação à pessoa e aos bens do filho menor não emancipado, exercido em igualdade de condições, por ambos os pais, para que possam desempenhar os encargos que a norma jurídica lhe impõe, tendo em vista o interesse e a proteção do filho.

Este poder poderá ser suspenso ou extinto por ato judicial, independentemente do modelo familiar que tenha sob seus cuidados uma criança ou adolescente, desde que este ofereça risco ao seu desenvolvimento pleno. Os pais que não cumprirem o dever de guarda, sustento e educação dos filhos, bem como as determinações judiciais, podem perder esse poder familiar. Ademais, perdem a guarda os pais ou responsáveis que castigar imoderamente, abandonar, praticar atos imorais (CECIF, 2005),violência doméstica e intra-familiar, ou ainda oferecer ambiente familiar que põe em perigo a vida da criança e do adolescente.

Porém, a pobreza e a miséria, apesar de não serem considerados motivos suficientes para a destituição do poder familiar (ECA, art. 23), são os motivos que mais levam ao abrigamento de crianças e adolesces no Brasil (SILVA, 2002).

A suspensão do Poder Familiar ocorre com a privação, por tempo determinado, de atributos referentes a um filho ou mais. É uma restrição imposta àquele que exerce o poder familiar que abusar de sua função prejudicando o filho. Contudo, os pais, quando tem 
suspenso o poder familiar, não são impedidos de manter contato com a criança ou adolescente, com exceção daqueles pais que cometeram crime cuja pena ultrapasse dois anos de reclusão (CECIF, 2005).

A Medida de Abrigamento para crianças e adolescentes é estabelecida pelo Estatuto da Criança e do Adolescente em seu artigo 101, inciso VII. Essa medida será adotada quando esgotadas todas as outras medidas de proteção:

\footnotetext{
I - encaminhamento aos pais ou responsável, mediante termo de responsabilidade;

II - orientação, apoio e acompanhamento temporários;

III - matrícula e freqüência obrigatórias em estabelecimento oficial de ensino fundamental;

IV - inclusão em programa comunitário ou oficial de auxílio à família, à criança e ao adolescente;

$V$ - requisição de tratamento médico, psicológico ou psiquiátrico, em regime hospitalar ou ambulatorial;

VI - inclusão em programa oficial ou comunitário de auxílio, orientação e tratamento a alcoólatras e toxicômanos;

VII - abrigo em entidade;

VIII - colocação em família substituta.
}

No artigo 98 do ECA é estabelecido que as crianças e adolescentes que tiverem seus direitos ameaçados ou violados, seja por ação ou omissão da sociedade ou do Estado, seja por falta, omissão ou abuso dos pais ou responsáveis, são colocadas em instituições de abrigamento provisoriamente e excepcionalmente.

O processo de abrigamento se inicia quando autoridades competentes - a Vara da Infância e da Juventude ou o Conselho Tutelar - verificam que aquelas medidas não surtiram efeitos, sendo necessária a separação da família natural. A partir disso, a criança e/ou adolescente é encaminhada provisoriamente para um abrigo convencional ou de acordo com as suas necessidades especiais, com o objetivo de resguardar a sua integridade física e afetiva, visando que as famílias consigam alcançar as condições necessárias para que seus filhos retornem ao convívio familiar. 


\section{Capítulo IV}

\section{A Proteção do Estado: do Abrigamento à Reintegração Familiar}

\subsection{A Política de Assistência Social - breve histórico}

No Brasil, até os anos 70, a garantia dos direitos sociais se restringia apenas aos trabalhadores inseridos no mercado de trabalho formal. Para a maioria de trabalhadores que não conseguiam ser absorvidos por aquele mercado, sobravam-lhes apenas o desemprego, subemprego ou as atividades precárias e informais, aumentando a desigualdade social e a exclusão social (BOSCHETTI, 2006).

A cidadania era status apenas para o cidadão assalariado que estava inserido no trabalho formal. A proteção social estava voltada para proteção do mercado de trabalho, ou seja, visava proteger apenas aqueles que contribuíam para o desenvolvimento econômico do país. A ideologia se circunscrevia baseada na lógica da integração ao mercado de trabalho, preconizando assim que inseridas no mercado de trabalho as pessoas teriam acesso à proteção social. Entretanto, Boschetti (2006) ressalta que diferentemente de outros países, essa sinergia não deu certo no Brasil, pois apesar do crescimento econômico, o âmbito social não conseguiu maiores avanços. Isso porque, sem o pleno emprego, a população não conseguiu alcançar os direitos ao trabalho e conseqüentemente à proteção social (idem).

$\mathrm{Na}$ atual Carta Magma, as políticas de Previdência, Saúde e Assistência passaram a compor o sistema de Seguridade Social (CF, 1988 art. 194). A idéia era que a proteção dessas políticas fosse universal, de modo que a previdência e a assistência se complementassem como nos países industrializados. Entretanto, a universalização entre as políticas não se concretizou na sociedade brasileira.

No Brasil, a seguridade social não conseguiu se estender como política universal, exceto a política de saúde. A previdência e a assistência são políticas que não abrangem toda a população brasileira. A previdência alcança apenas aqueles que estão inseridos no mercado de trabalho formal, excluindo a maioria dos trabalhadores que está no setor informal. Assim, não há como essa política se constituir em universal, quando apenas a minoria é protegida por ela e o mercado não absorve toda a população.

A política de Assistência Social, desde o seu processo histórico no Brasil, mostrou-se mais emblemática. A assistência, antes do seu estabelecimento na atual Carta Magma (art. 203), se restringia a ações pautadas no assistencialismo e benemerências, oferecidas por 
instituições privadas. Mesmo configurando um direito social, após sua inserção na atual CF de 1988, ela foi usada como uma política "stricto sensu", sem sistematização, esporádica e semelhante ao assistencialismo, usada para práticas clientelistas.

Neste sentido, essa política se configurava como um instrumento de dominação e de controle social, usada para a reprodução social. A falta de uma lei que a regulamentasse impedia a população de acessá-la como um direito social. O processo de regulamentação foi bastante árduo, pois havia interesses políticos, ideológicos, econômicos e sociais, e ainda não havia defensores dessa política.

De acordo com Boschetti (2006), após o Serviço Social reconhecer a Assistência Social como seu campo de trabalho e intervenção profissional, em 1962, foi que a luta se fortaleceu e encaminhou-se para a aprovação do projeto de lei que resultou na aprovação da Lei Orgânica da Assistência Social, em 1993, passando a integrar a Assistência Social como um dos tripés da Seguridade Social, com a especificidade de PROTEÇÃo Social.

A referida lei prevê que a Política de Assistência Social deve ser viabilizada de forma integrada com outras políticas, como as setoriais, de modo que a primeira política deve se articular com aquelas outras, visando maior interação e ação. Essa articulação entre políticas permite que ações sejam direcionadas para solucionar problemas que as políticas setoriais não deram contar de resolver.

O conceito de Assistência Social para Simões (2008) é traduzido nos artigos 203 e 204 da Carta Magma como política de Seguridade Social de responsabilidade (dever) do Estado e direito do cidadão. Neste sentido, o Estado passa a ter a obrigação de oferecer os bens, recursos e serviços a qualquer cidadão que deles tiver necessidades, recebendo-os como um direito sem nenhuma contribuição em contrapartida, rompendo com aquela concepção de assistencialismo de outrora.

O referido autor afirma que esse marco da Assistência Social, como direito assegurado na LOAS, concebe a assistência como instituição constitucional, isto é, integrante da política do Estado sob uma nova configuração que caminha no sentido de alcançar a cidadania (reconhecimento) das famílias e de vários segmentos necessitados (idem).

Para compreender melhor a Política de Assistência Social, Pereira (1996) ressalta que se deve entender o caráter contraditório dessa política. Desse modo, explica que por um lado a Assistência Social pode ser denominada de stricto sensu, aquela que serve ao capitalismo e usada para dominar os trabalhadores (a política usada antes da sua regulamentação) e, por outro lado, como política lato sensu, usada para garantir os direitos sociais dos indivíduos. 
O conceito da Política de Assistência Social será apreendido sob esta última dimensão. A Assistência Social se materializa como um instrumento utilizado pela sociedade para exigir que a atenção do Estado se volte para os seus membros, buscando concretizar direitos garantidos na legislação e conquistados pela sociedade para diminuir a pobreza e a exclusão social das famílias necessitadas.

Na concepção de Pereira (1996), a política de assistência social é condição necessária para que as políticas de atenção às necessidades sociais se efetivem como direitos de todos, ao passo que sem a integração de políticas setoriais há uma tendência a privilegiar mais a exclusão do que a inclusão dos indivíduos.

A autora explica que por não ser uma política especializada, a Assistência Social possui um caráter orgânico que permite a intercomunicação com as políticas setoriais, visando à diminuição da desigualdade social. Além disso, ela é a única que tem o ofício de lidar com os segmentos populacionais que permanecem na base piramidal do âmbito social, e se consagra como meio de denúncia da cidadania não implementada (PEREIRA, 2006).

No âmbito da Proteção Social, essa política deve garantir e oferecer aos indivíduos algumas seguranças, dentre elas a segurança de sobrevivência, acolhimento, convívio ou vivência familiar. A segurança de sobrevivência visa a uma garantia de que todos tenham um rendimento que garanta sua sobrevivência, independentemente de limitações para o trabalho ou emprego. A segurança de acolhimento é voltada para o provimento das necessidades humanas, como alimentação, vestuários e abrigo. E, por fim, a última segurança é aquela voltada para o convívio familiar e o fortalecimento das relações da instituição familiar (PNAS, 2004).

Sob esta concepção, a LOAS, em seu art. $1^{\circ}$, menciona: "A assistência Social, direito do cidadão e dever do Estado, é política de Seguridade Social não contributiva, que provê os mínimos sociais, realizada através de um conjunto integrado de ações de iniciativa pública e da sociedade, para garantir o atendimento às necessidades sociais".

Essa política pública visa proteger a maternidade, os portadores de deficiência, a velhice, a família, a infância e a adolescência. Para isso, oferece Benefícios de Prestação Continuada (BPC), Benefícios Eventuais, Serviços Assistenciais, Programas e Projeto de Enfrentamento da Pobreza (LIMA, 2003). Esse modelo de Assistência Social, estabelecido na LOAS, traduz-se em grande avanço para aquelas famílias que não conseguem oferecer aos seus membros as condições mínimas que assegurem a sua sobrevivência, contando assim com os benefícios dessa assistência. 
Além disso, o estabelecimento da co-responsabilidade da sociedade civil e do Estado, no sentido de executar ações para aliviar esses segmentos necessitados, é um grande passo para que essas famílias alcancem a cidadania. Contudo, os critérios estabelecidos para que os indivíduos necessitados recebam essa assistência são estigmatizantes, tendo em vista ser uma política voltada para pobres, baseada no critério de renda, que gera um impasse à mobilização dos segmentos necessitados na pirâmide social.

\subsubsection{O Estado e a Proteção à Família}

Nas comunidades tradicionais, a família era a única instituição que cumpria com as funções de reprodução e proteção social dos indivíduos. No período pós-guerra, o Estado, numa tentativa de substituir algumas de suas funções, foca apenas no desenvolvimento do indivíduo em particular, como o segmento infantil, a mulher, o idoso etc. (CARVALHO, 2003).

Na contemporaneidade, o Estado reconhece a importância da instituição familiar, que ganha centralidade na atenção às políticas sociais, sendo pensada como ente co-responsável no desenvolvimento dos indivíduos. Segundo Carvalho (2003), a família e o Estado são elementos fundamentais que devem oferecer em conjunto suportes aos indivíduos, pois cada qual possui bens, serviços e mercadorias que o mercado não consegue proporcionar.

No artigo 226 da CF 1988, a família ganha proteção Especial do Estado, o qual fica responsável em oferecer serviços para prevenção e superação das situações advindas das mazelas sociais que afetam indiretamente os direitos das crianças e adolescentes, sendo estes os mais prejudicados nesse contexto.

Carvalho e Almeida (2003) fazem uma análise sobre o contexto social dos anos noventa, constatando que nesse período as famílias passaram por modificações e foram afetadas pelas conseqüências trazidas pela introdução do neoliberalismo no Brasil. Essas autoras mencionam que houve redução e precarização dos postos de trabalho, aumento do desemprego estrutural, afetando negativamente a economia dos provedores das famílias e, conseqüentemente, suas funções e o convívio familiar. A miséria e a pobreza são categorias que a partir desse período cresceram massivamente, resultando em falta de recursos e engendrando nas famílias um estado de vulnerabilidade social, desencadeando situações conflitantes entre os membros familiares.

Nesse período, sob a concepção do Estado democrático de Direito, constata-se que para os indivíduos alcançarem a inclusão e o desenvolvimento social, o Estado deve intervir 
por meio de políticas públicas para reduzir a desigualdade social a níveis aceitáveis (SIMÕES, 2008). Assim, para diminuir essa desigualdade, implanta-se a Política de Assistência Social sob a responsabilidade do Estado e controle da sociedade, tendo como escopo a família para a concepção e implementação de benefícios, programas e projetos com o objetivo de garantir aos indivíduos desprovidos de recursos o atendimento às suas necessidades básicas.

Sob essa concepção de proteger a instituição familiar, a Assistência Social vem concretizar os art. 23 e 203, do ECA, que visam à proteção e à inserção da família nos programas de auxílio para que os seus filhos permaneçam em seu convívio e não sejam colocados em instituição de abrigamento. Entretanto, é importante frisar que o sistema de proteção a essas famílias ainda não consegue dar conta da demanda existente. Sem esse suporte do aparato institucional retarda-se cada vez mais a reintegração familiar, tendo em vista que muitas crianças foram abrigadas por motivos de falta de recursos financeiros (SILVA, 2004).

\subsection{A co-responsabilidade na garantia dos direitos do segmento infanto-juvenil}

A co-responsabilidade em cuidar do segmento infanto-juvenil é estabelecida no artigo 227, o qual obriga não só a família, mas a sociedade e o Estado a assegurarem àquele segmento com absoluta prioridade "o direito à vida, à saúde, a alimentação, à educação, ao lazer, à profissionalização, à cultura, à dignidade, ao respeito, à liberdade e à convivência familiar e comunitária, além de colocá-los a salvo de toda forma de negligência, discriminação, exploração, violência, crueldade e opressão".

A família é a principal instituição para que esses indivíduos possam se desenvolver de forma saudável. Entretanto, nem todas as famílias possuem as condições socioeconômicas favoráveis para suprir as condições mínimas, a fim de assegurar o pleno desenvolvimento dos filhos. A maioria das famílias brasileiras é pobre ou está imersa em condições sociais deploráveis, vítimas da exploração engendrada pelo sistema capitalista, e por isso não conseguem prover as condições mínimas de sobrevivência.

A Sociedade Civil exerce um papel fundamental na assistência e no enfrentamento dos problemas que acometem o segmento infanto-juvenil. A política de atendimento dos direitos da criança e do adolescente, estabelecida pelo ECA, prevê a participação do Estado e da Sociedade Civil em proteger todos os direitos desse segmento. 
A participação da Sociedade pode se dar por meio dos Conselhos Tutelares, cuja função é fiscalizar os direitos previstos no referido estatuto - se estão sendo cumpridos. Ainda, pode participar nos Conselhos de Direitos das Crianças e dos Adolescentes, colaborando na formulação e no controle da execução das políticas sociais e assegurando os direitos desse segmento. Além disso, a sociedade civil também pode participar como executoras de uma das medidas de proteção previstas no ECA, a Medida de Abrigamento. Essa medida de abrigamento poderá ser executada por meio de entidades e organizações de assistência social, não-governamentais, representando a Sociedade Civil na questão da coresponsabilidade desse segmento populacional. Para isto, essas entidades e organizações devem se inscrever no Conselho Municipal de Assistência Social ou no Conselho de Assistência Social do Distrito Federal, conforme o caso (LOAS, art.9).

O Estado, por sua vez, é um dos principais co-responsáveis na efetivação dos direitos das crianças e adolescentes, além de ser responsável pela política de assistência social, cujo instrumento dá condições para a efetivação desses direitos. Entretanto, a Sociedade Civil tem apresentado maior participação nos serviços prestados. No levantamento Nacional de Abrigos, realizado em 2004, as entidades não-governamentais prestaram mais serviços de abrigamentos do que as entidades governamentais (SILVA, 2004), constituindo, dessa forma, uma problemática, no sentido que aquelas instituições não possuem recursos próprios e suficientes para o pleno atendimento de todo os serviços de que sua demanda específica necessita.

\subsubsection{A atuação da Casa de Ismael na garantia dos direitos sociais do seu público-alvo}

A medida de abrigamento far-se-á diante de uma situação extrema, visando proteger crianças e adolescentes sob ameaça ou violação dos seus direitos que estejam sofrendo em sua própria família. Os casos são encaminhados pela Vara da Infância e da Juventude, Abrigos e pelos Conselhos Tutelares. Nestes dois últimos casos, a instituição deverá avisar àquela autoridade judiciária em 48 horas acerca do abrigamento.

O acompanhamento direto dos sujeitos abrigados é de responsabilidade do Serviço Social da instituição no sistema casa-lar. A finalidade desse trabalho é buscar garantir os direitos desse segmento infanto-juvenil e proporcionar o seu desenvolvimento biopsicológico e social. Além disso, faz o acompanhamento de suas famílias com ênfase na reintegração familiar. 
Para isso, a atuação do profissional de Serviço Social é interdisciplinar com outros setores da Saúde, Educação, Psicologia e Médico da Instituição, o que possibilita a ampliação do conhecimento aliado a outros saberes, além de contribuir para o atendimento integral daquele segmento e permitir que se faça uma intervenção mais adequada.

O desafio é promover uma intervenção que atenda aos usuários no intuito de resolver suas necessidades, bem como tentar abreviar o período do afastamento e assegurar o retorno para as suas famílias em condições seguras (SILVA, 2004).

Entretanto, o profissional de Serviço Social enfrenta vários desafios para garantir que os sujeitos abrigados acessem os direitos. Um dos desafios é realizar de forma rápida e eficiente as suas funções na instituição, diante das condições de trabalho que são bastante precárias. Primeiro, porque existe apenas um profissional de Serviço Social que atua com a proteção e garantia dos direitos desses sujeitos na instituição de abrigamento e, ao mesmo tempo, para fazer o acompanhamento das famílias. Segundo, que os equipamentos de trabalho são poucos e sucateados. Afora isso, a falta do suporte de pessoal auxiliar para executar diversas tarefas de natureza administrativas sobrecarrega esse profissional, de forma que acaba afetando o bom desenvolvimento de suas funções.

Os outros desafios pautam-se em assegurar os direitos sociais como saúde, educação, lazer, cultura, profissionalização e a convivência familiar e comunitária. Em relação à saúde, o problema se inicia dentro da própria Instituição, que não tem renda suficiente para garantir de forma permanente o trabalho da equipe técnica, como médico, psicólogo, nutricionista, etc., na instituição. Esses profissionais são voluntários, com pouca disponibilidade para atender à demanda do abrigo, que necessita de cuidados especiais. A mesma dificuldade é encontrada no acesso à rede pública de saúde cujos profissionais são insuficientes e os equipamentos estão sucateados, sem condições de atender toda a demanda em tempo hábil.

Assim, em casos urgentes, resta procurar a rede privada de serviços da saúde para que o abrigado possa ter o atendimento e não ter conseqüências piores diante da violência que sofreu. Porém, a dificuldade pauta-se na falta de recursos financeiros destinados às instituições não-governamentais que recebem apenas uma quantia per capita do governo e doações de entidades privadas para arcar com os custos das crianças e adolescentes abrigados. Neste sentido, percebe-se o desrespeito do Estado para com esse segmento infanto-juvenil, quando na atual Constituição Federal é estabelecida a prioridade nas ações direcionadas a esse segmento, que estão em desenvolvimento, mas na verdade as ações ficam apenas no papel.

O direito à educação de qualidade para esses usuários também é uma constante na pauta do assistente social da instituição, uma vez que muitas crianças e adolescentes, devido 
às diversas situações que passaram, apresentam aspectos que devem ser trabalhados na escola de forma especial. São indivíduos extremamente carentes de atenção e afeto, muitas vezes atrasados em relação à série escolar correspondente à sua idade, o que dificulta a integração e a relação com outros alunos com idades diferentes, merecendo muita atenção, pois esses e outros motivos poderão fazê-los perder o interesse pela escola.

Em relação à profissionalização desse segmento, a partir dos 14 anos de idade, esses jovens passam a participar do Programa Primeiro Passo para o Trabalho, fundamentado na lei 10.997/2000, também conhecida como Lei do Aprendiz. O objetivo é preparar o adolescente na formação pessoal e profissional, possibilitando condições para ele alcançar sua autonomia e independência. Este trabalho tanto prepara o adolescente para ser integrado ao mercado de trabalho, como se constitui numa forma de prepará-lo para o futuro desligamento da Instituição, dando condições, por meio do trabalho, para afastar novas situações de vulnerabilidade social. Entretanto, esse trabalho depende da sociedade, para que esses adolescentes sejam inseridos no mercado de trabalho, cujos postos são mínimos e exigem a especialização das funções.

Em relação ao lazer e à cultura, a instituição tem um projeto cuja denominação é Projeto Experimental Educinema, que consiste na apresentação de filmes, na abordagem de diversos temas sobre o aprendizado, sobre comportamentos humanos e questões sociais, permitindo que adolescentes e jovens de 14 a 18 anos, com o apoio de facilitadores, debatam acerca das temáticas propostas visando à transformação pessoal e social.

A garantia ao direito da Convivência Familiar e Comunitária constitui-se numa forma mais emblemática para o profissional de Serviço Social. Primeiro porque os motivos que levam as crianças e adolescentes ao abrigamento são os mais diversos e complexos possíveis. Muitas vezes, depende da própria família entender a importância em assegurar os direitos desse segmento - que está em desenvolvimento. Segundo, partindo para outra dimensão, a solução do problema não depende apenas das famílias, mas de políticas públicas efetivas como trabalho, educação, habitação, saúde, entre outras. Neste sentido, a assistente Social, visando à reintegração familiar, faz o estudo investigativo e análise da realidade social de cada família. A partir do estudo social elabora o Relatório Informativo, cujo parecer tem apenas o poder de sugerir ao Juiz da Vara da Infância e da Adolescência ações ou inserções das famílias em programas assistenciais que visem modificar e superar a situação de vulnerabilidade social e exclusão social.

No âmbito da família, as ações do Serviço Social pautam-se na orientação acerca dos direitos do segmento infanto-juvenil, direitos e responsabilidades dos familiares (inclusive a 
família extensiva), até o atendimento e esclarecimentos sobre os direitos à assistência social para superação da falta de condições, bem como a realização de ações que preservem os vínculos familiares. Além disso, nas famílias extensivas dos abrigados busca-se verificar o interesse dessas na reintegração desses sujeitos e fazer um trabalho de sensibilização da importância do convívio familiar para o desenvolvimento saudável desses sujeitos, com ênfase na reintegração familiar.

\subsection{Os Serviços de Proteção às Famílias dos Sujeitos abrigados}

Para que as famílias dos sujeitos abrigados superem suas dificuldades e situações de vulnerabilidade social, a Assistente Social da Casel faz um Estudo Social da realidade dessas famílias, informando ao Juiz da Vara da Infância e da Juventude - DF, e emitindo um Parecer Social por meio do Relatório Informativo, que sugere a essa autoridade algumas providências e ações que devem ser feitas, como inserção das famílias em serviços e programas governamentais. A tabela 3 mostra algumas das Redes de Serviços sugeridas ao Judiciário, visando à superação das dificuldades encontradas nas famílias dos sujeitos abrigados.

Tabela 3. Serviços de Proteção Social às Famílias dos sujeitos pesquisados

\begin{tabular}{|l|l|l|}
\hline Família & Encaminhamento & Objetivo \\
\hline I, II, IV & CRAS & $\begin{array}{l}\text { Inclusão da família em programas para promoção e } \\
\text { acompanhamento familiar. }\end{array}$ \\
\hline I, V e VI & CREAS & $\begin{array}{l}\text { Inclusão em grupo de atendimento a pessoas com } \\
\text { direitos violados. }\end{array}$ \\
\hline VIII VI, VII e & HUB & $\begin{array}{l}\text { Inclusão de genitores em programa de tratamento de } \\
\text { alcoolismo. }\end{array}$ \\
\hline III & IML & $\begin{array}{l}\text { Elaborar exame psiquiátrico, para saber se os genitores } \\
\text { têm condições mentais em se responsabilizar pelos } \\
\text { filhos. }\end{array}$ \\
\hline I e VIII & CT & $\begin{array}{l}\text { Acompanhamento e orientação da família nas suas } \\
\text { dificuldades de reestruturação }\end{array}$ \\
\hline
\end{tabular}

Elaboração própria. julho, 2009.

O Centro de Referência Básica (CRAS) é integrante da Rede de Proteção Social Básica, cujo foco é a prevenção de situações de risco, desenvolvendo potencialidades e 
aquisições e fortalecendo os vínculos familiares e comunitários. Essa proteção é destinada à população em situação de vulnerabilidade social advinda da pobreza, privação de recursos ou serviços, e que estejam com vínculos afetivos fragilizados (PNAS, 2004).

No universo de oito famílias, como mostra a tabela 3, apenas três famílias (I, II, IV) foram encaminhadas para o CRAS, todas em extrema situação de vulnerabilidade social e com necessidades de melhorias em suas moradias, conforme a tabela 1. Ainda, relacionando estas duas tabelas, observa-se que as famílias III, V e VIII necessitam de recursos materiais para melhorar as condições de moradia, não sendo atendidas pelo referido serviço por possuir os critérios para o acesso. A família VII, cuja situação era extremamente miserável, não foi atendida, pois sua família extensiva da genitora não sabia onde encontrá-la, e o genitor morava com a família materna que já recebia o BPC, não podendo acessar outro programa em função do critério de renda.

Diante disto, verifica-se que a maioria das famílias deveria ser inclusa em programas governamentais para que supere as dificuldades que implicam no retardamento do retorno dos sujeitos abrigados. Porém, a focalização da Política de Assistência Social atende apenas aqueles que estão em estado de pobreza extrema, de modo que, aqueles que não estão nesse estado, podem futuramente vir a fazer parte desse segmento, pois não tem nenhum apoio que os façam ascender na pirâmide social.

Outro problema que foi verificado refere-se à tramitação do pedido e à inserção dessas famílias nos Serviços de Proteção às famílias em situação de vulnerabilidade social. No primeiro caso, segundo a Assistente Social da Casa de Ismael, há uma grande demora até que o pedido solicitado, por meio do Parecer Social, seja analisado pelo Juiz da VIJ, haja vista a grande demanda de processos diversificados e mais urgentes analisados por esse Juiz. Ao analisar o Parecer Social, o processo é encaminhado para o Ministério Público, que faz a apreciação e manda de volta àquele juiz para despachar favoravelmente ou não.

Após o deferimento, as famílias são encaminhadas para serem atendidas pelo CRAS. No entanto, a segunda dificuldade pauta-se na espera pelo atendimento do CRAS, cuja capacidade para atender sua demanda é de até 1000 famílias/ano (PNAS/2004). Isso significa que muitas famílias têm de esperar muito tempo para que sejam atendidas. Sem acesso aos recursos para superar a condição de pobreza e miséria extremas não é possível abreviar o tempo de abrigamento de seus filhos, implicando na morosidade do atendimento das famílias pelas políticas sociais para superar suas dificuldades.

O Centro de Referência Especializada de Assistência Social (CREAS) integra a Rede de Proteção Social Especial, na modalidade Média Complexidade, cujo objetivo é direcionar 
ações de orientação, proteção e acompanhamento psicossocial às famílias e indivíduos com os direitos violados, objetivando orientar e estabelecer o convívio sócio-familiar e comunitário (SIMÃO, 2008). De acordo com os dados da pesquisa, foram encaminhadas para este serviço duas famílias que cometeram Violência Sexual contra seus filhos, a fim de serem atendidas em grupos destinados às pessoas com direitos violados.

Uma das redes que mais foi solicitada para a inclusão de famílias em seu programa foi o HUB, para tratar do alcoolismo dos genitores, conforme mostrado na tabela 3. No entanto, ressalta-se que para superar esse problema é necessário que o alcoólatra se reconheça como doente e compreenda a necessidade do tratamento para livrar-se do vício. Neste sentido, nenhum dos genitores das famílias II, VI, VII, VIII que bebiam conseguiu superar o vício, desde o abrigamento dos filhos. Por outro lado, dificuldades financeiras e a falta de profissionais suficientes e qualificados para acompanhar as famílias alcoólatras podem gerar grande impasse no resgate do paciente para continuar o tratamento.

\subsection{O tempo de abrigamento dos sujeitos pesquisados}

Tabela 4. Perfil do tempo das crianças e adolescentes

\begin{tabular}{|c|c|c|c|c|}
\hline Família & $\begin{array}{c}\mathbf{N}^{\mathbf{0}} \text { de filhos } \\
\text { abrigados }\end{array}$ & $\begin{array}{c}\text { Ano do } \\
\text { abrigamento }\end{array}$ & $\begin{array}{c}\text { Data da saída } \\
\text { do abrigo }\end{array}$ & $\begin{array}{c}\text { Total de anos } \\
\text { abrigados }\end{array}$ \\
\hline I & $02 *$ & 1997 & 2008 & 11 anos \\
\hline II & 02 & 1998 & -------- & 11 anos \\
\hline III & 03 & 1999 & 2008 & 11 anos \\
\hline IV & 02 & 2008 & 2009 & 01 ano \\
\hline V & 01 & 2001 & -------- & 08 anos \\
\hline VI & 01 & 1999 & --------- & 10 anos \\
\hline VII & 01 & 1999 & 2008 & 09 anos \\
\hline VIII & 02 & 2006 & -------- & 03 anos \\
\hline
\end{tabular}

Elaboração própria. Junho, 2009

* Essa família teve mais quatro filhos abrigados anteriormente.

Em geral os sujeitos pesquisados foram abrigados ainda quando criança, um com 01 ano, outros aos 03 anos e a maioria entre os 06 anos de idade. Grande parte das crianças foi abrigada com os seus irmãos. Porém, o que mais ressalta, de acordo com a tabela 4 , refere-se ao tempo de abrigamento dos sujeitos pesquisados. A maioria vive ou viveu mais de 10 anos no abrigo. Isso significa que passou quase toda sua infância e/ou adolescência nessa 
instituição, o que implica dizer que tiveram o direito à convivência familiar e a comunidade, assegurado no art. 19 do ECA, negado pela suas famílias e/ou pelo Estado.

Ainda, observa-se nesta tabela que quando foi feito um trabalho mais efetivo, algumas crianças conseguiram ser reintegradas às suas famílias de origem de forma mais rápida, como no caso da família IV.

\subsection{O trabalho da CASEL com as famílias dos sujeitos abrigados visando à reintegração} familiar

A casa de Ismael, visando à reintegração familiar, oferece um serviço denominado Apoio e Orientação Familiar (ASFAM), cuja finalidade é o fortalecimento da função protetiva da família, mediante apoio e orientação para superar situações decorrentes da fragilidade social, visando à recuperação de vínculos afetivos e, na medida do possível, oferecendo condições materiais para que se alcance a reintegração familiar.

É um trabalho de caráter assistencial feito por voluntários, técnicos e estagiários. O grupo articula-se com instituições como Federação Espírita de Brasília, Casa do Ceará, Igreja Católica, Projeto Aconchego, CEAL, ONGs e entidades privadas, para assim receber materiais de construção, cestas básicas, remédios, serviços de saúde oferecidos às famílias. Além de oferecer suporte psicossocial para que as famílias superem as condições desfavoráveis advindas da pobreza, miséria e vulnerabilidade social.

Com este trabalho desenvolvido pelo grupo acima descrito, e em alguns casos somados aos benefícios governamentais, foi possível fazer a reintegração de cinco crianças que foram pesquisadas, sendo duas crianças na família IV e três adolescentes na família VII. Ainda, durante a pesquisa a instituição preparava duas famílias para receberem seus filhos que atingiram a maioridade na instituição.

Depreende-se desses resultados que o Estado está falhando com a proteção social a essas famílias e está passando a sua responsabilidade para a Sociedade Civil. A falta de recursos para aqueles programas assistenciais, bem como a insuficiência de profissionais qualificados no atendimento às famílias só tem demonstrado, mais uma vez, a prioridade dada ao desenvolvimento do sistema econômico em detrimento do social, implicando em maior desigualdade social das famílias que acabam violando os direitos do segmento infanto-juvenil, afastando-os do convívio familiar e comunitário. 
O Estado deve cumprir o seu dever, pois é sua responsabilidade oferecer políticas sociais efetivas para que as famílias, em situação de extrema pobreza, miséria e vulnerabilidade social, superem suas necessidades sociais e consigam modificar sua situação social, de forma a possibilitar o retorno dos filhos para o convívio familiar. 


\section{Considerações Finais}

Os motivos que mais ensejaram na aplicação da medida de abrigamento dos sujeitos pesquisados retirados do lócus familiar e abrigados na Casa de Ismael foram o abandono, seguido pela negligência e maus tratos. Dessa forma, foi possível confirmar a segunda hipótese de que a violência doméstica por meio da negligência, abandono, maus tratos e abuso sexual é o fator que mais influencia no abrigamento do segmento infanto-juvenil.

Dentre as dificuldades enfrentadas pelas famílias de origem dos sujeitos pesquisados, foram encontrados os seguintes percalços a serem superados para que fosse possível a reintegração familiar daqueles sujeitos:
a) Alcoolismo;
b) Inacessibilidade ao trabalho;
c) Situação financeira desfavorável;
d) Habitações insalubres;
e) Fragilidade do vínculo afetivo; e
f) Problemas psicológicos.

A partir dessas dificuldades elencadas acima, foi possível responder à primeira hipótese de que os fatores sociais, econômicos, afetivos, culturais, simbólicos e psicológicos implicam na ruptura familiar e também dificultam o processo de reintegração familiar.

Para superação dessas dificuldades familiares, as medidas adotadas pela instituição de abrigamento, por meio do trabalho do Serviço Social, foram sugerir ao Juiz da Infância e da Juventude para o encaminhamento das famílias, de acordo com as particularidades de cada uma, a serviços como CREAS, CRAS, CT, HUB e IML; e acompanhar e orientar às famílias a respeito das suas dificuldades, buscando a superação destas últimas.

Assim, ficou constatado a inserção das famílias nas redes de serviços sociais e programas direcionados ao auxílio e proteção familiar, a fim de que elas recebessem suporte material, financeiro, psicológico e social para superação da vulnerabilidade social e problemas familiares.

A partir dessa constatação, foi possível fazer uma análise da efetivação desses serviços, fazendo uma relação entre o acesso das famílias e aqueles serviços e programas, de forma que se confirmou a hipótese 3, na qual as redes de serviços, bem como os programas direcionados ao auxílio e proteção familiar não conseguem oferecer às famílias de crianças e adolescentes abrigados condições suficientes para que possam superar sua situação de 
vulnerabilidade social, cuja decorrência advém da pobreza e privações, como condições de habitação, segurança alimentar, trabalho, geração de renda e saúde. Implicando, dessa forma, na morosidade ou até mesmo na impossibilidade da reintegração familiar dentro da perspectiva do Estatuto da Criança e do Adolescente, que estabelece a brevidade da medida de abrigamento.

Partindo dessas constatações, foi possível responder à pergunta inicial: Por que crianças e adolescentes, em situação de abrigamento, permanecem institucionalizados por muito tempo, ao invés de serem reintegrados em suas famílias de origem, de acordo com o que preconiza o Estatuto da Criança e do Adolescente?

De um lado há grandes deficiências dos serviços sociais em atender toda a demanda em tempo hábil; ainda, há a falta de acompanhamento dos serviços e da articulação entre as políticas voltadas para a infância e políticas de atendimento às famílias em situação de pobreza e vulnerabilidade social. Por outro lado, existe também a dificuldade que algumas famílias têm de reconhecer o alcoolismo como doença e sua necessidade do tratamento, de forma que, tudo isso implica na dificuldade do retorno dos seus filhos abrigados ao convívio familiar.

Paralelamente às ações sugeridas ao Juiz da VIJ, a instituição pesquisada, como foi visto no capítulo IV, empreende ações de caráter assistencial (grupo ASFAM), no sentido de viabilizar ações para possibilitar às famílias a superação de suas dificuldades e buscar, de forma mais rápida, uma possível reintegração familiar.

Neste sentido, percebe-se que o Estado é quem deveria oferecer essa retaguarda a essas famílias, por meio de políticas públicas efetivas. No entanto, ele tem falhado no amparo a essa instituição familiar que sem trabalho, sem acesso aos benefícios sociais e por causa da inoperância dos sistemas de proteção, que deveria lhes oferecer suporte, acaba por dificultar a superação das condições de vulnerabilidade social dessas famílias. Essa situação colabora para que o direito à convivência familiar e comunitária das crianças e adolescentes seja negado.

Além disso, o Estado está transferindo sua responsabilidade na execução dessa medida de abrigamento, uma vez que a maioria desses abrigos são instituições não-governamentais, sem suporte financeiro suficiente para arcar com todas as despesas dos usuários e dos prestadores de serviços.

Assim, sob a perspectiva do acesso aos direitos, compreende-se a urgência na universalização da política de assistência social, para que não haja seletividade nem focalização dos usuários, de modo que todas as famílias possam acessar essa política, 
prevenindo as situações futuras de pobreza, miséria e vulnerabilidade social, para que não haja repercussão na violação dos direitos das crianças e adolescentes.

O Estado deveria ser responsabilizado pelo descaso que as famílias dos abrigados estão vivenciando, bem como pelo desrespeito ao direito das crianças e adolescentes em assegurar a convivência familiar e comunitária. Uma vez que no Estatuto da Criança e do Adolescente está preconizada a brevidade dessa medida, mas a maioria deste segmento infanto-juvenil está passando sua infância e/ou adolescência nestas instituições.

A partir desses resultados, sugere-se que haja uma articulação entre as políticas de atendimento à criança e ao adolescente e as de proteção às famílias em situação de vulnerabilidade, no sentido de que se possa fazer um trabalho conjunto, para que a demanda das famílias e dos abrigados sejam atendidas, e as famílias sejam retiradas do estado de vulnerabilidade social, garantindo o direito à convivência desse segmento infanto-juvenil. Pois, famílias submetidas às condições de vidas precárias, sem garantia de alimentação, habitação em boas condições, saúde, assistência e, principalmente, o acesso ao trabalho, não conseguem superar suas dificuldades e ter de volta, em curto período de tempo, o retorno dos seus filhos abrigados.

Cabe ressaltar ainda que as situações de pobreza e miséria não devem ser enfrentadas apenas com a assistência social, pois esta apenas ameniza o sofrimento dos segmentos necessitados, pelos critérios que lhes são impostos. No entanto, a pobreza deve ser enfrentada com mais geração de postos de trabalhos e empregos para essas famílias, distribuição da riqueza social produzida, educação, saúde e cidadania para todos os indivíduos. Nesta perspectiva a assistência social deve funcionar apenas como um complemento para os indivíduos, garantindo a estes a construção de sua emancipação e cidadania. 


\section{Referências Bibliográficas}

101 Perguntas e respostas sobre reintegração familiar: $O$ trabalho a partir dos sistemas de acolhimento institucional e familiar. CeCif, São Paulo, 2005.

ANTUNES, Ricardo. Adeus ao trabalho?: ensaio sobre as metamorfoses e a centralidade do mundo do trabalho. $10^{\text {a }}$ ed. São Paulo: Cortez, 2005.

AMARO, Sarita. Crianças maltratadas e serviço social: subísidios à abordagem profissional. IN: Revista Serviço Social \& Realidade (Faculdade de História, Direito e Serviço Social - UNESP) Franca, SP, Brasil, Volume 15, nº 1, 2006.

ARPINI D. M. \& QUINTANA A. M. Identidade, Família e Relações Sociais em Adolescente de grupos populares. Rev. Estudos de Psicologia, PUC-Campinas, v. 20, n. 1, p. 27-36, janeiro/abril 2003.

AZÔR, A. M. G. C. C. V; \& VECTORE Celia. Abrigar/desabrigar: conhecendo o papel das famílias nesse processo. 2008 IN: http://www.scielo.br/pdf/estpsi/v25n1/a08v25n1.pdf. Acesso em: 28 dez. 2008, 15 hs.

BALISTA, Carolina; BASSO, Emiliana; COCCO, Marta; GEIB, Lorena T. C Representações sociais dos adolescentes acerca da violência doméstica. Revista Eletrônica de Enfermagem, v. 06, n. 03, 2004. Disponível em www.fen.ufg.br

BARROS, Nivia Valença. Violência intrafamiliar contra criança e adolescente.Trajetória histórica, políticas sociais, práticas e proteção social. Orientadora: Maria Euchares de SennaMotta. - Rio de Janeiro: PUC-Rio, Departamento de Psicologia, 2005. Tese (doutorado) -Pontifícia Universidade Católica do Rio de Janeiro, Departamento de Psicologia.

BOWLBY, John, 1907. Formação e Rompimentos dos laços afetivos; tradução Álvaro Cabral; revisão Luiz Lorenzo Rivera. São Paulo: Martins Fontes, 1982

$\mathrm{BACH}$, J. Marcos. O futuro da família: tendências e perspectivas. Petrópolis: Editora Vozes, 1983.

BALISTA, Carolina; BASSO, Emiliana; COCCO, Marta; GEIB, Lorena T. C Representações sociais dos adolescentes acerca da violência doméstica. Revista Eletrônica de Enfermagem, v. 06, n. 03, 2004. Disponível em www.fen.ufg.br

BARROS, Nivia Valença. Violência intrafamiliar contra criança e adolescente.Trajetória histórica, políticas sociais, práticas e proteção social /Nivia Valença Barros; orientadora: Maria Euchares de SennaMotta. - Rio de Janeiro : PUC-Rio, Departamento de Psicologia,2005.

BARDIN, Laurence. Análise de Conteúdo. Lisboa: Ed. 70, 1995. 225p.

BARSTED, Leila Linhares. Permanência ou Mudança? O discurso legal sobre a família. IN: ALMEIDA, Ângela Mendes de. Pensando a família no Brasil: Da colônia à modernidade. Rio de janeiro: Espaço \& Tempo, 1987 
BORGES, A. Impactos do desemprego e da precarização sobre famílias metropolitanas. R. bras. Est. Pop., São Paulo, v. 23, n. 2, p. 205-222, jul./dez. 2006

BOSCHETTI, Ivanete. Seguridade social e trabalho: paradoxos na construção das políticas de previdência e assistência Social no Brasil. Brasília: Letras Livres: Editora UnB, 2006.

BRASIL. Constituição da República Federativa do Brasil (1988). Pinto, A. L. T.; Windt, M. C.V. S; Céspedes, Lívia. 41ed. atual. e ampl. São Paulo: Saraiva, 2008.

Estatuto da Criança e do Adolescente. Secretária Especial dos Direitos Humanos; Ministério da Educação, Assessoria de Comunicação social. Brasília: MEC, ACS, 2005.

Lei Orgânica da Assistência Social, LEI No 8.742, de 07 de dezembro de 1993.

Presidência da República. Secretaria Especial dos Direitos Humanos. Conselho Nacional dos Direitos da Criança e do Adolescente. Plano Nacional de Promoção, Proteção e Defesa do Direito de Crianças e Adolescentes à Convivência Familiar e Comunitária / Secretaria Especial dos Direitos Humanos. - Brasília-DF : Conanda, 2006.

Secretaria Nacional de Assistência Social, Ministério do Desenvolvimento Social e Combate à Fome. Política Nacional de Assistência Social - PNAS/2004. Brasília, 2004.

CARVALHO, Inaiá Maria Moreira de, ALMEIDA, Paulo Henrique de. Família e Proteção Social. São Paulo Perspec., V. 17, n. 2, p. 109-122, São Paulo, 2003.

CARVALHO, M.C.B. Famílias e políticas públicas In:VITALE, Ana Rojas; VITALE, Maria Amália. Família: Redes, laços e políticas públicas. São Paulo: IEE/PUCSP, 2003.

CAVAlCANTE, Cinthia Mendonça; JORGE, Maria Salete Bessa. Mãe é a que cria: o significado de uma maternidade substituta. Estud. psicol. (Campinas), Campinas, v. 25, n. 2, June 2008 Disponível em: <http://www.scielo.br/scielo.php?script=sci_arttext\&pid=S0103-

166X2008000200011\&lng=en\&nrm=iso>. Acesso em: 21, nov. 2008, 16hs.

CERVO, A. L. \& BERVIAN, P.A. Metodologia Científica. $4^{\text {a }}$ Ed. São Paulo; Makron Booke;1996

CRESWELL, John W. Projeto de Pesquisa: métodos qualitativo e misto, 2. ed. Porto Alegre: Artmed, 2007. 248 p. ISBN 9788536308920

FALEIROS, Vicente de Paula; FALEIROS, Eva Silveira. ESCOLA QUE PROTEGE: Enfrentando a violência contra crianças e adolescentes. Brasília: Ministério da Educação, Secretaria de Educação Continuada, Alfabetização e Diversidade, 2008, $2^{a}$ edição.

AMAS, Família de crianças e adolescentes: Diversidade e movimento. Belo Horizonte: AMAS, 1995.

FAVERO, Eunice Teresinha. Rompimentos dos vínculos do pátrio poder: condicionantes socioeconômicos e familiares. São Paulo, editora Veras, 2001. 
GIL, Antonio Carlos. Métodos e técnicas de pesquisa social. $6^{\text {a }}$ ed. São Paulo: Atlas, 2008.

GOLDENBERG, Mirian. A arte de Pesquisar: como fazer pesquisa qualitativa em Ciências Sociais. $7^{\mathrm{a}}$ Ed. Rio de Janeiro: Record, 2003.

GOMES, Mônica Araújo; PEREIRA, Maria Lúcia Duarte. Família em situação de vulnerabilidade social: uma questão de políticas públicas. Ciênc. saúde coletiva, Rio de Janeiro, v. 10, n. 2, Apr. $2005 \quad$. $\quad$ Available from $<$ http://www.scielo.br/scielo.php?script=sci_arttext\&pid=S1413-

81232005000200013\&lng=en\&nrm=iso>. access on12 Apr. 2009. doi: 10.1590/S141381232005000200013 .

IBGE. Estudos e Pesquisas Informação Demográfica e Socioeconômica, número 17. Síntese de indicadores Sociais, 2005.

KALOUSTIAN, Sílvio Manoug. Família brasileira, a base de tudo. $3^{\text {a }}$ edição. São Paulo: Cortez, Brasília, DF: UNICEF, 1988.

LIMA, A. D. As regras legais e o processo de descentralização da Assistência Social. IN: Ser Social: Revista do Programa de Pós-Graduação em Política Social/universdiade de Brasília. Departamento de Serviço Social - V. 1 n. 1(1º semestre, 1998), Brasília, Ser Social UnB, 1998.

MARCÍLIO, Maria Luiza. A roda dos expostos e a criança abandonada na História do Brasil. 1726-1950. IN: FREITAS, Marcos Cesar de (org). História Social da Infância no Brasil. São Paulo: Cortez, 1997. 312 p.

NOGUEIRA, Paula Cristina e COSTA, Liana Fortunato. Mãe social: profisssão? função materna?. Estilos clin. [online]. dez. 2005, vol.10, no.19 [citado 28 Julho 2008], p.162181.Disponível

em: <http://www.pepsic.bvspsi.org.br/scielo.php?script=sci_arttext\&pid=S141571282005000200 010\&lng=pt\&nrm=iso>. ISSN 1415-7128. Acesso em: 28 jul. 2008, 10hs.

PEREIRA, Potyara A. P. Assistência Social na Perspectiva dos Direitos: crítica aos padrões dominantes de proteção aos pobres no Brasil. Brasília: Thesauros, 1996. (capítulos 2 e 3 - páginas 33 a 57).

Rabelo, uma vila sem pais. Correio Brasiliense, 19 de outubro de 2008, p. 37.

Relatório de Atividades, Balanço e Demonstração de Resultado. Casa de Ismael, 2008. Aprovado em março de 2009.

RODRIGUES, A. Alves; CARVALHO, D. B. Birche. A violência doméstica contra crianças e adolescentes: análise do fenômeno no Distrito Federal. IN: SER SOCIAL 02. Violência e exploração sexual contra crianças e adolescentes. Brasília, 1998.

ROSA, Elizabete Terezinha Silva. A centralidade da família na política de assistência social. In: I CONGRESSO INTERNACIONAL DE PEDAGOGIA SOCIAL, 1., 2006, . Proceedings online... Faculdade de Educação, Universidade de São Paulo, Available from: $<$ http://www.proceedings.scielo.br/scielo.php?script=sci_arttext\&pid=MSC00000000920060 00100011\&lng=en\&nrm=abn>. Acesso em: 21 nov. 2008. 
SILVA, Enid Rocha Andrade. O direito à convivência familiar e comunitária: os abrigos para crianças e adolescentes no Brasil. Brasília: IPEA/CONANDA, 2004.416p.:Il.

SILVA. Lygia Maria Pereira da. Violência doméstica contra a criança e o adolescente. Recife: EDUPE, 2002. 240 p. : il.

SIMÕES, Carlos. Curso de Direito do Serviço Social. $2^{\text {a }}$ Ed. Ver. E atual. São Paulo: Cortez, 2008.

SIQUEIRA, Aline Cardoso; DELL'AGLIO, Débora Dalbosco. O impacto da institucionalização na infância e na adolescência: uma revisão de literatura. Psicol. Soc., Porto Alegre, v. 18, n. 1,2006. Disponível em: <http://www.scielo.br/scielo. php?script $=$ sci_arttext $\&$ pid $=S 0102-71822006000100010 \& \operatorname{lng}=$ en $\&$ nrm $=\mathrm{iso}>$. Acesso em: 29 agost. 2008. doi: 10.1590/S0102-71822006000100010/S0103-166X2008000200011.

VENÂNCIO, Renato Pinto. Famílias abandonadas: Assistência a criança de camadas populares no rio de janeiro e em salvador: século xviii e xix. Campinas: Papirus, 1999. 190p.

VOLIC, Catarina. e BAPTISTA, Veras Myrian. Aproximações ao conceito de negligência. IN: Revista Serviço Social e Sociedade. São Paulo; Cortez. Ano XXVI - no 83, 2005.

WEBER, L. N. D. (2004) A evolução das relações parentais: uma abordagem etólogica. Psicologia Argumento, 22(38), 19-26. 


\section{Anexos}

\section{Anexo I - Síntese das Famílias}

Família I - Trata-se de uma família cuja genitora teve vários filhos de pais diferentes, e dentre esses, seis receberam a medida de abrigamento. A genitora é analfabeta, tem problemas de saúde, não trabalhava e apenas seu companheiro fazia alguns trabalhos esporádicos. A situação de habitação sempre foi extremamente precária, e raramente com algumas melhoras. Houve dois abrigamentos cujos motivos foram o "abandono total da mãe", e a situação miserável da família, respectivamente. Todos os filhos abrigados só saíram da instituição de abrigamento quando atingiram a maioridade.

Família II - Os genitores dessa família são separados e são dependentes do alcoolismo, tiveram duas filhas que foram abrigadas. A genitora, sem escolaridade, apresentava instabilidade no emprego e nos seus relacionamentos. Sua habitação é bastante precária. As crianças foram abrigadas devido ao abandono pelos genitores, que dificilmente mantinham contanto com elas, quando abrigadas. O genitor é aposentado, e por questões de saúde parou de fazer uso de álcool, dessa forma o único impeditivo para reintegrar as filhas era a construção de cômodos para acomodar as jovens

Família III - Os genitores eram alcoólatras, sendo que a genitora veio a falecer por excesso de bebida. Tiveram quatro filhos, desses três crianças foram abrigadas e o outro ficou sob os cuidados da tia paterna. $\mathrm{O}$ genitor é aposentado por problemas psiquiátricos e após a morte de sua esposa, passou a viver com outra companheira. Parou de beber, mas o problema psiquiátrico não possibilitava administrar sua renda, nem condições psicológicas para se responsabilizar pelos cuidados dos filhos. Os filhos também apresentam problemas psicológicos. Os abrigados só saíram da instituição de abrigamento ao atingir a maioridade, ficando sob a curatela do filho mais velho, que passou a administrar a renda do genitor.

Família IV- Uma família monoparental, em que a genitora é a única a se responsabilizar pelos cuidados e educação dos filhos. Cursou até $7^{\mathrm{a}}$ série do nível fundamental. Trabalha, mas sua renda não aufere o suficiente para melhorar sua situação de vida. O genitor trabalha e vive com outra família, mas não tem qualquer responsabilidade com os filhos. O motivo do 
abrigamento deu-se pelo "abandono da mãe" e resistência dos infantes em retornar ao convívio com a genitora que os negligenciavam/ maltratavam. Entretanto, foi constatado que os motivos eram apenas a falta de condição socioeconômica e as precárias condições de moradia da genitora. O retorno das crianças ao convívio familiar só foi possível após a inclusão da família em programa governamental, a qual passou a receber os benefícios, como a construção de cômodos na casa da genitora, possibilitada pela ASFAM, bem como a responsabilidade do genitor em assumir um dos filhos.

Família V- Os genitores, quando crianças viveram em instituição de abrigamento. A genitora não apresenta condições psicológicas para criar o filho, já tentou suicídio e sofre de depressão. $O$ genitor cursou até a $6^{a}$ série, não possui emprego nem condições de habitação favoráveis para a reintegração familiar. O motivo de abrigamento deu-se por suspeita do genitor abusar sexualmente do filho e prendê-lo em cárcere privado. Entretanto, nada foi comprovado. Há fortes vínculos entre genitor e o filho, contudo, sem trabalho e sem condições salubres de moradia, a reintegração familiar não pode ser concretizada.

Família VI - É outra família monoparental, mas que recebe o apoio financeiro do genitor da criança. Trata-se de uma genitora que é alcoólatra e foi acusada de abusar sexualmente do filho. O genitor não quer contato com o filho, visto que este foi oriundo de uma relação extraconjugal. A genitora tem casa própria, recebe a Pensão Alimentícia do filho, mas gasta todo dinheiro para comprar bebidas alcoólicas. As transformações necessárias para que aconteça a reintegração familiar pautam-se na superação do vício, estabilidade financeira, bem como, o fortalecimento dos vínculos afetivos.

Família VII - Os genitores dessa família são moradores de rua, dependentes de álcool e drogas. A genitora teve 07 filhos de pais diferentes, desses cinco foram abrigados, onde três estão sob os cuidados da tia paterna, outro com a madrinha, outro foi assassinado e outra mora com os avôs paternos. Os motivos que ensejaram no abrigamento foram a solicitação de abrigamento, tendo em vista a falta de moradia. O outro motivo foi o abandono e a negligência da genitora com os filhos. A genitora não tinha nenhum vínculo afetivo com os filhos. Desses abrigados, sabe-se que duas adolescentes e uma criança (irmãos) foram reintegradas na família extensiva, tia paterna. 
Família VIII- Os genitores são alcoólatras e ainda há a suspeita de uso de drogas entorpecentes. O motivo de abrigamento foi em virtude dos Maus Tratos e Negligência dos genitores. A genitora mora com um companheiro, ambos são desempregados, fazem "bicos" para auferir alguma renda para o seu sustento. A habitação é feita de maderite e apresenta condições de insalubridade. Diante das precárias condições socioeconômicas e dificuldades apresentadas, a genitora tentou se suicidar tomando uma cartela de remédios. O genitor é morador de rua e vigia de carros. A outra família do genitor (mãe, irmãos) também é dependente do alcoolismo, além de não ter boas condições socioeconômicas. A reintegração familiar depende da mudança desse quadro apresentado pelos genitores. 
Anexo II - Autorização da Casa de Ismael para realizar a Pesquisa 


\section{Anexo III - Modelo de Relatório Informativo}

\section{CASA DE ISMAEL}

Exm. Sr.

Dr.

MM. Juiz de Direito da Vara da Infância e Juventude DF

Autos de Pasta Especial no Adolescente/Criança

\section{RELATÓRIO INFORMATIVO}

\section{IDENTIFICAÇÃO}

Nome:

Data de Nascimento:

Filiação:

\section{HISTÓRICO}

3. ACOMPANHAMENTO DA FORMAÇÃO DO ABRIGADO

3.1 CONVIVÊNCIA FAMILIAR-COMUNITÁRIA

3.2CONVIVÊNCIA FAMILIAR-BIOLÓGICA

3.3 EDUCAÇÃO

3.4 NUTRICIONAL

3.5 PATRIMONIAL

3.6 PROFISSIONALIZAÇÃO

3.7 PSICOLÓGICO

3.8 SAÚDE

\subsection{ESPORTES}

